\title{
Bioethanol Production from Renewable Raw Materials and Its Separation and Purification: A Review
}

\author{
Arijana Bušić ${ }^{1}$ Nenad \\ Marđetko', Semjon \\ Kundas², Galina Morzak³, \\ Halina Belskaya ${ }^{3}$, Mirela \\ Ivančić Šantek', Draženka \\ Komes', Srđan Novak' \\ and Božidar Šantek ${ }^{1 *}$
}

'University of Zagreb, Faculty of Food Technology and Biotechnology, Pierottijeva 6, HR-10000 Zagreb, Croatia

Belarussian National Technical University, Power Plant Construction and Engineering Services Faculty, Nezavisimosti Ave. 150, BY-220013 Minsk, Belarus

${ }^{3}$ Belarussian National Technical University, Mining Engineering and Engineering Ecology Faculty, Nezavisimosti Ave. 65, BY-220013 Minsk, Belarus

Received: 22 October 2017 Accepted: 21 May 2018

\footnotetext{
*Corresponding author:

Phone: +38514605290;

Fax: +38514836424

E-mail: bsantek@pbf.hr
}

ORCID IDs: 0000-0002-3572-5752 (Bušić), 0000-0002-3857-9818 (Marđetko), 0000-0002-9577-4556 (Kundas), 0000-0003-2638-8157 (Morzak), 0000-0002-4351-8825 (Belskaya), 0000-0002-5935-6672 (Ivančić Šantek), 0000-0002-9062-1673 (Komes), 0000-0001-9583-534X (Šantek)

\section{SUMMARY}

Production of biofuels from renewable feedstocks has captured considerable scientific attention since they could be used to supply energy and alternative fuels. Bioethanol is one of the most interesting biofuels due to its positive impact on the environment. Currently, it is mostly produced from sugar- and starch-containing raw materials. However, various available types of lignocellulosic biomass such as agricultural and forestry residues, and herbaceous energy crops could serve as feedstocks for the production of bioethanol, energy, heat and value-added chemicals. Lignocellulose is a complex mixture of carbohydrates that needs an efficient pretreatment to make accessible pathways to enzymes for the production of fermentable sugars, which after hydrolysis are fermented into ethanol. Despite technical and economic difficulties, renewable lignocellulosic raw materials represent low-cost feedstocks that do not compete with the food and feed chain, thereby stimulating the sustainability. Different bioprocess operational modes were developed for bioethanol production from renewable raw materials. Furthermore, alternative bioethanol separation and purification processes have also been intensively developed. This paper deals with recent trends in the bioethanol production as a fuel from different renewable raw materials as well as with its separation and purification processes.

Key words: bioethanol, renewable feedstocks, raw material pretreatment, bioprocess operational modes, bioethanol separation and purification

\section{BIOREFINERY AND BIOETHANOL PRODUCTION}

Fossil resources are still primary energy and chemical sources; around $75 \%$ is used for heat and energy production, about $20 \%$ as fuel, and just a few percent for the production of chemicals and materials (1). Natural regeneration of fossil resources through the carbon cycle is significantly slower than their current rate of exploitation. A small number of countries possess the major reserves of fossil fuels, which additionally increases unsustainability of their production. Furthermore, increased greenhouse gas emission arises from fossil fuel combustion and land-use change as a result of human activities, and consequently results in an acceleration of the global warming crisis $(2,3)$. In most developed countries, governments stimulate the use of renewable energies and resources with following major goals: (i) to secure access to energy, (ii) to mitigate climate changes, (iii) to develop/maintain agricultural activities and (iv) to ensure food safety. Affordable energy, climate change and social stability, as the three pillars of sustainability, are directly related to the above mentioned major goals $(1,4)$. Current situation of global warming and all fossil-based problems could be successfully altered by replacing fossil with renewable resources, which are more uniformly distributed and cause fewer environmental and social concerns (3).

During the last decades of the 20th century, there was an enormous interest in the production and usage of liquid biofuels (biodiesel or bioethanol) as promising substitutes for fossil fuels. Biofuels manufactured from plant-based biomass represent renewable energy resources. The use of this feedstock would reduce fossil fuel consumption and consequently the negative impact on the environment (5-7). Development of biorefinery aims to fulfil the sustainability criteria for biofuel production. Biorefinery is an integrative and 
multifunctional concept that uses biomass for the sustainable production of different intermediates and products as well as the complete possible use of all feedstock components (8). The concept includes selective transformation of the different molecules available in the biomass into biofuels, but also into pharmaceuticals, pulp, paper, polymers and other chemicals, as well as food or cattle feed $(9,10)$. A wide range of technologies are able to separate biomass resources into their building blocks, like carbohydrates, proteins, fats, etc. (3). The plant that produces lignocellulose-containing raw materials could be a good example of biorefinery concept where cellulose and hemicellulose produce simple (fermentable) sugars and lignin produces target compounds (e.g. polymers, resins, pesticides, levulinic acid and other materials). Recently, there have been considerable efforts to improve selectivity and efficiency of lignin depolymerization and upgrading processes for the target compound production. The catalytic hydrodeoxygenation process is the most promising way for target compound production from lignin (11-13).

In general, the biorefinery process usually comprises the following stages: pretreatment and preparation of biomass, separation of biomass components and subsequent conversion and product purification steps. There are two basic approaches for biorefinery concept implementation: bottom-up and top-down. Bottom-up biorefinery approach is characterized by the spreading of current biomass processing facilities (the production of only one or a few products) into a biorefinery with the aim to obtain an enlarged range of products and/ or an increase of usable biomass fractions through the connection to additional technologies. An example of bottom-up biorefinery is the wheat and corn starch biorefinery (Lestrem, France) that starts as a simple starch factory. It gradually expanded the number of products, like starch derivatives and starch modifications, chemicals and fermentation products. A corn starch biorefinery in the USA (Decatur, Illinois) and wood lignocellulosic biorefineries in Austria (Lenzing) and Norway (Sarpsborg) also use bottom-up approach (8).

The new top-down approach is a highly integrated system established for the use of various biomass fractions and generation of different products for the market (zero-waste generation). The objective is to obtain the complete use of biomass a)

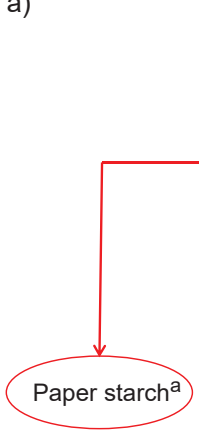

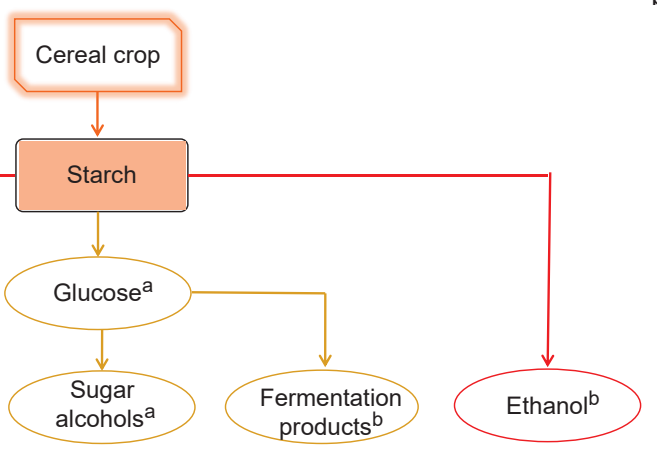

b)

(e.g. wood lignocellulose, grain and straw from cereals or green grasses). An example of top-down approach is Austrian Green Biorefinery. It uses green grass silage as feedstock for the production of biobased products like proteins, lactic acid, fibres and biogas from the remaining biomass. Furthermore, green grass juice and silage juice (complex nitrogen and phosphate sources) served as cultivation medium constituents for growth and polyhydroxyalkanoate production by Wautersia eutropha $(14,15)$. Top-down biorefineries are still at the research and development stages and their demonstration plants are mainly based in the USA, Europe and some other industrialized countries (8). The examples of bottom-up and top-down biorefinery concepts are given in Fig. 1 (8).

However, both biorefinery concepts still need a lot of engagement to fulfil all requirements for production of high-quality biofuels, value-added chemicals or other products, mainly in terms of the optimisation and upgrading of existing conversion processes, development of new processes and products with justified costs, and the industrial scale-up of existing ideas.

Bioethanol, as an alternative to the fossil fuels, is mainly produced by yeast fermentation from different feedstocks. It is a high octane number fuel and its physicochemical features are considerably different compared to the gasoline (Table $1 ; 6$ ).

Bioethanol serves mostly in the transport sector as a constituent of mixture with gasoline or as octane increaser (ethyl tertiary butyl ether (ETBE), consisting of $45 \%$ per volume bioethanol and $55 \%$ per volume of isobutylene). Many countries use ETBE instead of methyl tertiary butyl ether (MTBE), which serves for octane number increase, but it is prohibited in the USA and Canada due to cancerous emissions. Bioethanol is mixed with gasoline at the volume fractions of 5, 10 and $85 \%$ (fuel names E5-E85). A total of $85 \%$ bioethanol by volume can only be used in flexible fuel vehicles (FFV), while mixtures of 5 and $10 \%$ by volume can be used without any engine modifications. However, problems related to the use of bioethanol are: corrosive effect on fuel injector and electric fuel pump (bioethanol is hygroscopic in nature), engine startup problem in cold weather conditions (pure ethanol is hard to vaporize) and the tribological effect on lubricant properties and engine performance. Bioethanol inside lubricant significantly reduces

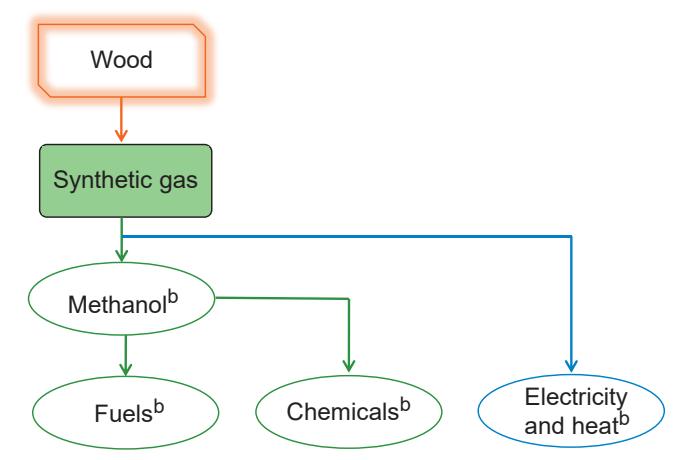

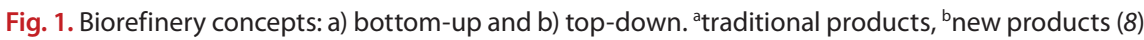


Table 1. Specifications of gasoline and ethanol (6)

\begin{tabular}{lll} 
Specification & Gasoline & Ethanol \\
Chemical formula & $\mathrm{C}_{\mathrm{n}} \mathrm{H}_{2 \mathrm{n}+2}(\mathrm{n}=4-12)$ & $\mathrm{C}_{2} \mathrm{H}_{5} \mathrm{OH}$ \\
$\mathrm{M} /(\mathrm{g} / \mathrm{mol})$ & $100-105$ & 46.07 \\
Octane number & $88-100$ & 108 \\
$\rho /\left(\mathrm{kg} / \mathrm{dm}^{3}\right)$ & $0.69-0.79$ & 0.79 \\
Boiling point $/{ }^{\circ} \mathrm{C}$ & $27-225$ & 78 \\
Freezing point $/{ }^{\circ} \mathrm{C}$ & -22.2 & -96.1 \\
Flash point $/{ }^{\circ} \mathrm{C}$ & -43 & 13 \\
Autoignition temperature $/{ }^{\circ} \mathrm{C}$ & 275 & 440 \\
Lower heating value $10^{3} /\left(\mathrm{kJ} / \mathrm{dm}{ }^{3}\right)$ & $30-33$ & 21.1 \\
Latent vapourisation heat $/(\mathrm{kJ} / \mathrm{kg})$ & 289 & 854 \\
Solubility in water & insoluble & soluble \\
\hline
\end{tabular}

the properties and performance of engine oil. It is miscible with water, but immiscible with oil. Therefore, bioethanol has high potential for emulsion formation (bioethanol-water-oil mixture), which causes serious engine failures. There are different methods to improve the performance of engines (e.g. laser texturing, coatings, mass reduction of engine parts and lubricant composition) and extend their lifetime through the friction and wear reduction. The use of synthetic oil is one possibility to solve the above-mentioned issues (16).

Data for 2016 show that the global bioethanol production was 100.2 billion litres (7). Annual bioethanol production is constantly increasing, and the prediction of worldwide bioethanol production and its consumption is an increase to nearly 134.5 billion litres by 2024 (Fig. 2; 17).

Fig. 2 shows that two-thirds of this increase will probably originate in Brazil mostly to fulfil domestic demand (17). In Brazil, increased demand for bioethanol is mostly due to the constant increase in the number of sold FFVs. Therefore, it is likely that the USA and Brazil will remain the two major bioethanol producers, followed by the European Union and China (17). About $40 \%$ of the global bioethanol production is from sugar cane and sugar beet and nearly $60 \%$ is from starch-containing feedstocks (18). In Europe, the most convenient renewable raw materials for bioethanol production are grains (mostly wheat) and sugar beet (19). In France they also made bioethanol from wine surplus (20). The prices of raw materials have a considerable impact on the bioethanol production costs and they can represent $40-75 \%$ of the total costs depending on the type of feedstock (21). The costs of bioethanol production from sugar cane in Brazil are in the range of $0.20-0.30$ USD/L. In the USA and European Union bioethanol produced from sugar beet and corn reached the lowest production costs of 0.30 and 0.53 USD/L, respectively $(22,23)$. The costs in China (wheat, sweet sorghum or cassava) are $0.28-0.46 \mathrm{USD} / \mathrm{L}$ depending on the feedstock costs. The cost of bioethanol production from the sugar-containing raw materials is around $0.44 \mathrm{USD} / \mathrm{L}$ in India, while from lignocellulose-containing raw materials it is 0.80 1.20 USD/L depending on the type of feedstock $(23,24)$. However, the gasoline production (refining) costs (0.10-0.18 USD/L depending on the type of refining process) are still lower (25) and bioethanol production costs are competitive only in Brazil. a)

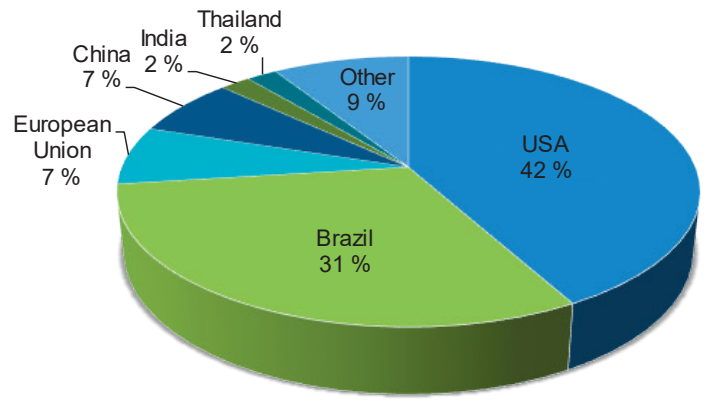

b)

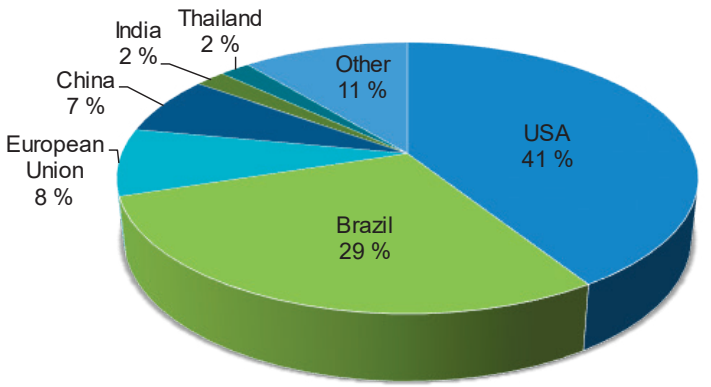

Fig. 2. Predictions of the world bioethanol production (a) and consumption (b) by 2024 (17)

The cost of bioethanol production can be partially compensated through the reduction of greenhouse gas emissions, energy supply security and stimulation of agricultural activities in rural regions $(22,23)$.

This work discusses conventional and alternative feedstocks for bioethanol production, bioprocess operational modes (batch, fed batch, repeated batch, etc.), and separation and purification of bioethanol from fermented broth.

\section{RAW MATERIALS AND THEIR PRETREATMENT FOR BIOETHANOL PRODUCTION}

Different types of biomass have a potential as raw materials for bioethanol production. Because of their chemical composition, i.e. carbohydrate sources, they mostly form three groups: (i) sugar-containing raw materials: sugar beet, sugarcane, molasses, whey, sweet sorghum, (ii) starch-containing feedstocks: grains such as corn, wheat, root crops such as cassava, and (iii) lignocellulosic biomass: straw, agricultural waste, crop and wood residues (26). However, these sugarand starch-containing feedstocks (first generation) compete with their use as food or feed, thus influencing their supply. Therefore, lignocellulosic biomass (second generation) represents an alternative feedstock for bioethanol production due to its low cost, availability, wide distribution and it is not competitive with food and feed crops (27).

\section{Raw materials that contain sugar}

Sugar cane and beet are the most important sugar-producing plants in the world. Two-thirds of the world sugar 
production are from sugar cane and one-third is from sugar beet (28). They can be easily hydrolysed by the enzyme invertase, which is synthesed by most Saccharomyces species. Therefore, the pretreatment is not required for bioethanol production from the feedstocks containing sugar (sucrose), which makes this bioprocess more feasible than from feedstocks containing starch (28). Sugar crops need only a milling process for the extraction of sugars to fermentation medium, and here ethanol can be produced directly from juice or molasses (29).

Sugar cane as a raw material for bioethanol production provides certain advantages, since it is a semi-perennial crop that does not require many agricultural operations that are usually needed for raw crop processing, and its biomass is used for heat and electricity. Sugar cane is less expensive than other raw materials used for bioethanol production (12) due to easier processing and higher productivity (30). However, many efforts still aim at the improvement of bioethanol production from sugarcane. This includes development of new sugar cane varieties with higher sugar contents and resistance to diseases, larger yield per hectare and greater longevity (26).

In Europe, sugar production is mainly based on the use of sugar beet as raw material. Raw, thin and thick juice, as intermediate formed during sugar beet processing, as well as high purity crystal sugar, could be converted into bioethanol and/or bio-based products. Raw sugar beet cossettes are also suitable substrates for bioethanol production $(31,32)$. The use of sugar processing intermediates determines bioprocess configuration, their microbiological stability and transport properties. Sugar syrup and granulated sugar can serve as substrates for bioethanol production during the whole year. Futhermore, they can also serve as precursors for different chemical intermediates or final products (e.g. surfactants; 8).

Molasses, a main byproduct of the sugar industry, serves mostly as a substrate for yeast, bioethanol and biochemical production, but it can also be suitable for feedstuff production (8). Total residual sugars in molasses can amount to 50$60 \%(\mathrm{~m} / \mathrm{V})$, of which about $60 \%$ is sucrose, which makes this substrate suitable for large-scale bioethanol production (33). Sugar cane and beet molasses are byproducts of the manufacture or refining of sucrose from sugar cane and beet. Cane molasses contains not less than $46 \%$ of total sugars and sugar beet molasses not less than $48 \%(\mathrm{~m} / \mathrm{V})$. Molasses is also a byproduct in the production of dried citrus pulp, with not less than $45 \%(\mathrm{~m} / \mathrm{V})$ total sugars. Glucose manufacture from starch (corn or grain sorghum; enzymes or acids are used for starch hydrolysis) also yields molasses. Starch molasses contains about $43 \%(\mathrm{~m} / \mathrm{V})$ reducing sugars and $73 \%(\mathrm{~m} / \mathrm{V})$ total solids (33).

Another sugar-containing material that can be used for bioethanol production is whey, a byproduct of cheese manufacture, containing around $4.9 \%(\mathrm{~m} / \mathrm{M})$ lactose. Due to the relatively low sugar content, a bioethanol plant of modest size requires a sizeable whey volume. The feasibility of a new bioethanol plant depends on the cost of whey permeate as feedstock as well as the final bioethanol price that is closely related to the production technology and bioprocess performance (34).

\section{Raw materials that contain starch}

Grain crops (e.g. corn, barley, wheat or grain sorghum) and root/tubular crops (e.g. cassava, potato, sweet potato, Jerusalem artichoke, cactus or arrowroot) contain large quantities of starch (35). Isolated native starch from different sources can be used for further conversion into bio-based products and/ or the bioethanol production. The residue from starch isolation contains proteins and fibre, which has a great potential for application in food and feed production (8). The biggest corn starch production is in the USA and it represents more than $80 \%$ of the worldwide market (35). In the USA, corn is a source of over $95 \%$ of bioethanol production and the rest is produced from barley, wheat, whey and beverage residues (36). The grain sorghum cultivating regions in the USA show an increasing interest in bioethanol production from this crop. Furthermore, the economic viability of bioethanol production from cassava in Thailand was also under investigation (5). Cassava tubers contain nearly $80 \%$ by mass starch and below 1.5 $\%$ by mass proteins. Pretreatment of cassava tubers for bioethanol production includes following operations: cleaning, peeling, chipping and drying. After that, the dried cassava chips are used for bioethanol production (5).

Starch is a mixture of linear (amylose) and branched (amylopectin) polyglucans. The crucial enzyme for starch hydrolysis is a-amylase, active on $\mathrm{a}-1,4$, but not on $a-1,6$ linkages in amylopectin (37). For bioethanol production from starch-containing feedstocks, it is necessary to perform the starch hydrolysis (mostly by a-amylase and glucoamylase) into glucose syrup, which can be converted into ethanol by yeast Saccharomyces cerevisiae. This step is an additional cost compared to the bioethanol production from sugar-containing feedstocks (38). Bacterium Bacillus licheniformis and genetically modified strains of bacterium Escherichia coli and Bacillus subtilis produce a-amylase, while moulds Aspergillus niger and Rhizopus sp. produce glucoamylases $(39,40)$.

Under anaerobic conditions, yeast S. cerevisiae metabolizes glucose into ethanol. The maximum conversion efficiency of glucose into ethanol is $51 \%$ by mass. However, the yeast also uses glucose for cell growth and synthesis of other metabolic products, thus reducing the maximum conversion efficiency. In practice, 40 to $48 \%$ by mass of glucose is actually converted into ethanol (41).

In comparison to ethanol production from sugar-containing raw materials, ethanol obtained from starch improves enzyme application and yeast strains with high ethanol tolerance (42).

Microalgae are a potential renewable source of biomass for biofuel production because they are capable of converting $\mathrm{CO}_{2}$ into lipids and polysaccharides. Therefore, industrial $\mathrm{CO}_{2}$ could be collected and used for cultivation of microalgae as part of strategy for reduction of $\mathrm{CO}_{2}$ emission in atmosphere. 
Microalgae can accumulate starch as a reserve polysaccharide, which can be used for bioethanol production (third generation) after pretreatment process. Furthermore, residual biomass (containing organic matter and minerals) after bioethanol production can serve as biofertilizer. Thus, it is obvious that the use of biorefinery concept can considerably improve bioethanol production from microalgae $(21,43)$.

\section{Raw materials that contain lignocellulose}

Production of bioethanol from the raw materials that contain lignocellulose is attractive and sustainable because lignocellulosic biomass is renewable and non-competitive with food crops. Furthermore, the use of bioethanol obtained from lignocellulosic biomass is related to the considerable reduction of greenhouse gas emission (44). Lignocellulosic biomass is almost equally distributed on the Earth, compared to the fossil resources, which provides security of supply by using domestic energy sources (38). It can be obtained from different residues or directly harvested from forest and its price is usually lower than of sugar- or starch-containing feedstocks, which require full agricultural breeding approach (3). Raw materials that contain lignocellulose for bioethanol production form six main groups: crop residues (cane and sweet sorghum bagasse, corn stover, different straw types, rice hulls, olive stones and pulp), hardwood (aspen, poplar), softwood (pine, spruce), cellulose wastes (e.g. waste paper and recycled paper sludge), herbaceous biomass (alfalfa hay, switchgrass and other types of grasses) and municipal solid wastes (45).

The average lignocellulosic biomass contains $43 \%$ cellulose, $27 \%$ lignin, $20 \%$ hemicellulose and $10 \%$ other components (3). Compositional variety of lignocellulosic biomass could be an advantage (availability of more products than obtained in petroleum refineries, and a broader range of feedstocks), but also a disadvantage (need for a large range of technologies; 46). Such heterogeneous structure of lignocellulosic biomass requires more complex chemical processes than uniform and consistent raw materials needed in chemical industry (47). Furthermore, harvesting of lignocellulosic crops is usually not possible throughout the whole year, which makes it more difficult for biomass suppliers. Therefore, this problem has to be solved by biomass stabilization in order to be available for long-term storage, and to ensure continuous work of biorefinery throughout the year (3).

The hydrolysis of lignocellulosic biomass to monomeric sugars is necessary before microorganisms can metabolize them. Acids, alkalines or enzymes usually perform this process. Physicochemical, structural and compositional factors can considerably slow down this process. Therefore, alkaline pretreatment step is usually necessary to obtain conditions for an efficient enzymatic hydrolysis (27). In the pretreatment, reduction of polymerization degree and crystallinity index $(48,49)$, disruption of the lignin-carbohydrate linkages (50), removal of lignin and hemicelluloses $(51,52)$ and increase of material porosity (53) have to occur in order to insure the efficient enzymatic hydrolysis of lignocellulosic biomass. The choice of pretreatment depends on the nature of the raw material and the formation of byproducts during the selected pretreatment, and its choice has a large impact on all subsequent stages in the bioethanol production (54).

Harsh conditions used during pretreatments lead to the synthesis of toxic compounds, like furans (2-furaldehyde (furfural) and 5-hydroxymethylfurfural (HMF)), carboxylic acids (acetic, formic and levulinic acids) and phenolic compounds (aldehydes, ketones, $p$-coumaric and ferulic acids). Because these compounds are potential yeast inhibitors, following strategies (to reduce their impact on the bioprocess performance) were proposed: (i) removal of inhibitors by solvent extraction, ion exchange, overliming, usage of zeolites, or enzyme laccase, (ii) use of yeast strains very tolerant to inhibitors, and (iii) selection of effective pretreatment that causes minimal sugar degradation and formation of inhibitors. Most detoxification methods only partially remove inhibitors, but they also contribute to the sugar loss, which additionally enlarges the final process costs (27). Recently, lignite served as adsorbent for detoxification of spurce sawdust hydrolyzates in the production of polyhydroxyalkanoates (PHA) by Burkholderia cepacia and Burkholderia sacchari (55). The use of lignite instead of activated carbon in detoxification is less efficient in the removal of inhibitors, but has a greater positive impact on the bacterial growth and PHA yield. Furthermore, lignite is a considerably cheaper adsorbent than activated carbon, which can improve bioprocess economic feasibility. Lignite used in detoxification can partially compensate for fermentation heat and energy demands (55).

Pretreatment methods could be basically divided in four main groups (physical, chemical, physicochemical and biological), where not all of the given methods are fully feasible for application on industrial scale $(27,56)$.

\section{Physical pretreatment of raw materials that contain lignocellulose}

Physical (mechanical) pretreatment includes milling (e.g. two-roll milling, ball or hammer milling and colloid or vibroenergy milling), irradiation (gamma ray, electron beam, microwave) and other (e.g. hydrothermal, expansion, extrusion or pyrolysis) methods. After physical pretreatments, the reduction in particle size and crystallinity of lignocellulosic biomass has an impact on the increase of specific surface area and reduction of the degree of polymerization (57). However, the particle size has to be optimized (very small particles are not desirable) because of high energy consumption during milling and negative impact on the pretreatment (58). Many of the mentioned size-reduction physical methods are not economically feasible due to the very high energy demands. Extrusion is a new and prospective physical pretreatment for biomass conversion into fermentable sugars. The capacity to ensure high shear rate, rapid heat transfer and effective mixing are the main extruder advantages (59). Yoo et al. (60) employed extrusion as pretreatment for conversion of soybean hulls to fermentable sugars, and compared it with two traditional 
pretreatments using dilute acid $\left(1 \%\right.$ by mass $\left.\mathrm{H}_{2} \mathrm{SO}_{4}\right)$ and alkali ( $1 \%$ by mass $\mathrm{NaOH}$ ). Under optimal conditions the authors revealed the highest cellulose to glucose conversion of $95 \%$ by mass.

\section{Chemical pretreatment of raw materials that contain lignocellulose}

Chemical pretreatments include acid (sulfuric, hydrochloric, phosphoric or nitric acid), alkali (sodium or potassium hydroxide, ammonia or ammonium sulfite), or gas treatment (chlorine dioxide, nitrogen dioxide or sulfur dioxide) as well as addition of oxidizing agents (oxygen, ozone, hydrogen peroxide), ionic liquids (imidazolium-based ionic liquids) and organosolv (methanol, ethanol, acetone, glycerol, ethylene glycol, etc.).

The main goal of employing acid pretreatment is to solubilize the hemicellulose, making the cellulose more accessible to enzymes. Acid pretreatments use concentrated or diluted acids (27). However, concentrated acids $\left(\mathrm{H}_{2} \mathrm{SO}_{4}\right.$ or $\left.\mathrm{HCl}\right)$ are good hydrolysis agents with corrosive and hazardous characteristics (57). The main disadvantage of acid hydrolysis is formation of inhibitors, since released fermentable sugars can be decomposed into furfural (from pentoses) and HMF (from hexoses). These compounds are yeast cell growth inhibitors which have negative impact on the bioethanol production efficiency (e.g. reduced yeast growth, ethanol yield and productivity; 61).

For alkaline pretreatment of lignocellulosic raw materials, $\mathrm{NaOH}, \mathrm{KOH}, \mathrm{Ca}(\mathrm{OH})_{2}$ and $\mathrm{NH}_{4} \mathrm{OH}$ are used most often. In this pretreatment lower temperature and pressure than in the other pretreatment methods are applied (51). Alkaline pretreatment increases cellulose digestibility and it is more effective for lignin solubilisation (62). However, high cost of alkalis is one of the major drawbacks (58). In a study of Cheng et al. (63), both $\mathrm{Ca}(\mathrm{OH})_{2}$ pretreatment (at $95^{\circ} \mathrm{C}$ ) and $\mathrm{NaOH}$ pretreatment (at $55^{\circ} \mathrm{C}$ ) significantly improved delignification of rice straw. Ozonolysis reduces lignin content (hemicellulose is slightly affected, while cellulose is not), and does not produce toxic residues, but larger ozone demands makes this method very expensive $(1,64)$. Wheat and rye straw (65), cotton straw (66), bagasse and poplar (64), sugarcane bagasse and straw (67) have been pretreated by ozone in order to examine the features of this pretreatment method.

The use of ionic liquids (ILs), salts usually composed of large organic cations and small inorganic anions, as solvents for lignocellulosic feedstocks pretreatment has also been intensively studied (68). ILs have a capacity to break the extensive hydrogen bonds in the polysaccharides and to stimulate their solubilization. They are characterized by thermal and chemical stability, nonflammability, wide liquid temperature range and good solvation features for various materials $(69,70)$. ILs are known as "green" solvents due to the fact that during their use toxic or explosive gases are not formed (27). During ILs pretreatment of switchgrass, significant increase of the enzymatic saccharification of xylan (63\% xylose yield in 24 h) and cellulose ( $96 \%$ glucose yield in $24 \mathrm{~h}$ ) was observed (71).
Combined method that uses ILs and ammonia was examined for rice straw pretreatment. Obtained results show that $82 \%$ of the cellulose from rice straw was recovered with $97 \%$ of the glucose conversion, significantly higher than the individual ammonia or ILs treatments (72). Pretreatment of wheat straw by using IL ([emim] $\left[\mathrm{CH}_{3} \mathrm{COO}\right]$ ) resulted in high purity cellulose and hemicellulose fractions as well as $87 \%$ pure lignin (73).

The organosolv is based on the use of organic or aqueous solvents (e.g. ethanol, methanol, acetone and ethylene glycol) to extract lignin and to ensure more accessible cellulose. In this pretreatment solvents are mixed with water in various portions, added to the biomass and heated (100-250 ${ }^{\circ} \mathrm{C}$; 74). However, solvents need to be drained from the reactor, evaporated, condensed and recycled, which makes the pretreatment costs relatively high. Organosolv extraction of sugarcane bagasse under optimized conditions (30\% by volume ethanol at $195{ }^{\circ} \mathrm{C}$ for $60 \mathrm{~min}$ ) results in the production of $29.1 \%$ by mass of fermentable sugars (75). Sun and Chen (76) studied the organosolv (glycerol-based) pretreatment of wheat straw. Under optimized conditions (liquid-solid ratio of $20 \mathrm{~g} / \mathrm{g}$ at $220^{\circ} \mathrm{C}$ for $3 \mathrm{~h}$ ) $70 \%$ by mass hemicelluloses and 65 $\%$ by mass lignin were removed from the lignocellulose-containing raw materials.

\section{Physicochemical pretreatment of raw materials that contain lignocellulose}

Physicochemical pretreatments include wet oxidation, explosion (steam explosion, ammonia fibre explosion, $\mathrm{CO}_{2}$ explosion, $\mathrm{SO}_{2}$ explosion), microwave, ultrasound and liquid hot water pretreatment. The steam explosion consists in the treatment of ground biomass with high-pressure saturated steam and then the pressure is quickly released, which causes an explosive decompression of biomass. It usually starts at $160-260{ }^{\circ} \mathrm{C}$ (corresponding pressure of $0.69-4.83 \mathrm{MPa}$ ) for a short time (several seconds to a few minutes) before the biomass is exposed to atmospheric pressure (77). During this pretreatment hemicellulose and lignin are degraded. This pretreatment is cost effective, but it also destroys a portion of the xylan fraction. During steam explosion incomplete disruption of lignin-carbohydrate matrix and generation of microbial inhibitors also occurred (64). Sugar cane bagasse was treated by steam explosion at 200,215 and $230^{\circ} \mathrm{C}$ for $5 \mathrm{~min}$ in the simultaneous saccharification and fermentation process of bioethanol production (78). The optimum pretreatment conditions $\left(215^{\circ} \mathrm{C}\right.$ for $5 \mathrm{~min}$ ) resulted in a total glucose yield of $86.8 \%$ by mass. Ammonia fibre explosion (AFEX) is an important pretreatment that utilizes physical (high temperature and pressure) and chemical (ammonia) processes to achieve effective feedstock hydrolysis. AFEX increases the surface accessibility for hydrolysis, promotes cellulose decrystallization and partial hemicellulose depolymerization and reduces lignin recalcitrance in the treated feedstock. However, this process is not efficient for biomass with high lignin content (64). Lau et al. (79) studied AFEX pretreatment and enzymatic hydrolysis of empty palm fruit bunch fibre (EPFBF), obtained from palm 
processing industry. The optimal conditions were: $135^{\circ} \mathrm{C}, 45$ min residence time, water to dry biomass loading of $1: 1(\mathrm{~g} / \mathrm{g})$, and ammonia to dry biomass loading of 1:1 (g/g), giving yield of $90 \%$ by mass of the total reducing sugars after $72 \mathrm{~h}$ of enzymatic hydrolysis.

Supercritical fluids are gaseous substances compressed at temperatures above their critical point to a liquid-like density. Water, carbon dioxide and ammonia are the most often used substances in supercritical form. Supercritical $\mathrm{CO}_{2}$ mostly serves as an extraction solvent because it is nontoxic, noninflammable, inexpensive, and readily available, and it does not cause formation of inhibitory compounds. In supercritical $\mathrm{CO}_{2}$ explosion, the explosive release of $\mathrm{CO}_{2}$ pressure disrupts the cellulose and hemicellulose fractions, and consequently increases the accessible surface area of the substrate for enzymes $(27,80)$. For the sugar cane bagasse pretreatment, supercritical $\mathrm{CO}_{2}$ and ultrasound served to improve the efficiency of enzymatic hydrolysis (81). In the pretreatment with only supercritical $\mathrm{CO}_{2}$ the amount of fermentable sugar increased 2.8 times compared to the untreated sugar cane bagasse and consequently the efficiency of enzymatic hydrolysis was $74.2 \%$ by mass. The combined ultrasound and supercritical $\mathrm{CO}_{2}$ pretreatment increased the amount of fermentable sugars after enzymatic hydrolysis by $16 \%$ by mass compared to the pretreatment with only ultrasound. These results lead to conclusion that the combined ultrasound and supercritical $\mathrm{CO}_{2}$ pretreatment is an efficient and prospective alternative for pretreatment of lignocellulose-containing raw materials at relatively low temperatures without the use of hazardous solvents (81).

Sulfite pretreatment to overcome recalcitrance of lignocellulose (SPORL; 82-85) is an efficient approach in the pretreatment of woody biomass (both hardwoods and softwoods). SPORL is efficient at $160-190^{\circ} \mathrm{C}$ for $10-30 \mathrm{~min}$. The sulfite addition increases the medium $\mathrm{pH}$ value, which consequently results in the synthesis of lower quantities of fermentation inhibitors $(82,83)$. The partial sulfonation of lignin by sulfite ensures wood softening, which considerably reduces energy demand for pretreatment. Comparison between acid-catalyzed steam explosion and SPORL shows that SPORL energy efficiency is about 30-fold higher (86). Enzymatic hydrolysis of softwood substrates pretreated by SPORL with enzyme loading of 15 FPU/g cellulose was approx. $95 \%$ by mass within only $48 \mathrm{~h}$ (83-86).

Microwaves also have application in the pretreatment of lignocellulose-containing raw materials. Many investigations have pointed out that microwaves cause localized heating of feedstock leading to disruption of lignocellulose structure, making cellulose and hemicellulose more accessible for enzymatic hydrolysis (87). Su et al. (88) studied the effects of microwave treatment on the Taiwan sorghum liquor waste. Results of this research indicate that reducing sugar yield was considerably higher than of the untreated waste.

Ultrasonic treatment of solutions has a potential use as an alternative technology, and it has been used for the extraction of cellulose, hemicellulose and lignin (89). Ultrasonic waves create pressure differences (cavitation) within a solution for the enhancement of physical and chemical processes. Bussemaker and Zhang (89) extensively wrote about the effect of ultrasound on the lignocellulosic biomass as pretreatment for biorefinery applications.

\section{Biological pretreatment of raw materials that contain lignocellulose}

In comparison to most of other pretreatments used, biological pretreatments are considered as environmentally friendly processes, since they do not employ chemicals, energy input is relatively low, there are no corrosion-related problems, no waste stream, and production of inhibitors is on the lowest level (90). In these pretreatments, microorganisms like brown, white and soft rot fungi degrade lignin and hemicellulose, but they are not effective in cellulose disruption (90). However, the rate of lignocellulose hydrolysis in biological processes is very low (64). The pretreatment of corn stover, wheat and soybean straw, switchgrass and hardwood by Ceriporiopsis subvermispora was studied by Wan and Li (91). After an 18-day pretreatment, C. subvermispora was capable of delignifying corn stover, switchgrass and hardwood by using enzymes manganese peroxidase and laccase. In this enzymatic hydrolysis, glucose yields were $56.50,37.15$ and $24.21 \%$ by mass, respectively, which is 2- to 3-fold higher than those observed with the untreated feedstocks. A further increase of glucose yield (by 10$30 \%$ by mass) was obtained when fungal pretreatment time was prolonged to 35 days. On the contrary, fungal pretreatment did not increase cellulose digestibility from wheat and soybean straw (91).

Biological pretreatment also includes the use of enzymes for hydrolysis of raw lignocellulosic materials. The overall bioprocess efficiency depends on the rate of lignocellulosic feedstock hydrolysis into fermentable sugars (44). Cellulases perform enzymatic hydrolysis of cellulose, so that yeasts or bacteria can then ferment the obtained reducing sugars into ethanol (57). In the hydrolysis of cellulose at least three major groups of cellulases take part: endoglucanases (attack regions of low crystallinity in the cellulose fibre creating free chain ends), exoglucanases (cellobiohydrolases; degrade the molecule further by removing cellobiose units from the free chain ends) and $\beta$-glucosidases (hydrolyze cellobiose to produce glucose; 92). Enzymatic hydrolysis can be actually divided into two stages: primary and secondary. Primary hydrolysis stage involves the action of endoglucanases and exoglucanases on the surface of solid substrate, resulting in the release of oligosacharides (up to 6 glucose units in chain) into liquid phase. Secondary hydrolysis stage includes further hydrolysis of oligosacharides to cellobiose (by cellobiohydrolase) and glucose (by $\beta$-glucosidases) (44).

The accessibility of cellulose to enzymatic hydrolysis depends on the xylan removal from lignocellulose by using xylanases. Xylan does not have the tightly packed crystalline structure like cellulose and therefore it is more susceptible to enzymatic hydrolysis. The complete hydrolysis of $x y-$ lan requires the cooperative action of the following enzymes: 
endo-1,4- $\beta$-xylanase, $\beta$-xylosidase, $\alpha$-arabinofuranosidase and $\alpha$-glucuronidase. Esterases act upon the ester linkages between xylose units of the xylan and acetic acid (acetyl xylan esterase) or between arabinose side chain residues and phenolic acids such as ferulic acid (ferulic acid esterase) and $p$-coumaric acid ( $p$-coumaric acid esterase; 44). Several species of bacteria and fungi are able to produce cellulases and hemicellulases $(57,93)$. Among these microorganisms, Trichoderma reesei was mentioned as the most efficient cellulose-hydrolysing organism (94).

Lignin is closely bound to cellulose and therefore it is not accessible for cellulases. The main characteristic of lignin degradation is the action of peroxidases where lignin peroxidase (also called ligninase) and manganese peroxidase (also called Mn-dependent peroxidase) are the two major enzymes (44). These enzymes were discovered in Phanerochaete chrysosporium and they are called true ligninases because of their high redox potential. Lignin peroxidase oxidizes nonphenolic lignin substructures (by taking out one electron) and produces cation radicals, which are further chemically degraded (44).

Laccase (benzenediol oxygen oxidoreductase) also takes part in the lignin degradation which is synthesized by the broad variety of white rot fungi (44). It has a capacity for complete lignin hydrolysis alone or in combination with other peroxidases. Laccases catalyze the oxidation of phenolic units in lignin (consequently molecular oxygen is reduced to water) as well as phenolic substances and aromatic amines to radicals. Phenolic substances (strictly related to lignin or lignin derivatives) as well as nonlignin substances and extracts from different resources stimulate lacasse synthesis (44).

Enzymatic hydrolysis is highly specific and it occurrs in milder reaction conditions (e.g. $\mathrm{pH}=5$ and temperature below 50 $\left.{ }^{\circ} \mathrm{C}\right)$ with lower energy consumption and environmental impact than the acid hydrolysis of lignocellulose. It also gives high glucose yield with low byproduct formation, which is favourable for further use of hydrolysate in fermentation. Enzymatic hydrolysis does not cause the corrosion problems (95). The final product of enzymatic hydrolysis (glucose) inhibits the enzyme activity and therefore it has to be removed immediately after formation to reduce its impact on the hydrolysis kinetics. Different approaches have been examined to reduce the glucose inhibition by hydrolysis such as the use of high enzyme concentrations, the addition of $\beta$-glucosidases during hydrolysis, and sugar removal during hydrolysis by ultrafiltration or simultaneous saccharification and fermentation (SSF; 38,96). Substrate concentration has a crucial impact on the initial rate and the yield of cellulose enzymatic hydrolysis. Increase of low substrate concentration increases yield and hydrolysis rate. Although cellulase price has been reduced more than a 10-fold in the last decades, it still represents more than $20 \%$ of bioethanol production costs from lignocellulosic feedstocks (1). Since cellulases remain active after hydrolysis, their recycling could be useful and economically feasible approach. Therefore, various methods for enzyme recycling (e.g. sedimentation followed by ultrafiltration or microcentrifugation, cation exchange chromatography, readsorption and immobilization) have been studied (44).

\section{BIOETHANOL PRODUCTION FROM RAW MATERIALS THAT CONTAIN SUGAR}

The most employed microorganism for bioethanol production from sugar-containing feedstocks is Saccharomyces cerevisiae due to its capacity to degrade sucrose into hexoses (glucose and fructose). The cells of S. cerevisiae require small amounts of oxygen for fatty acid and sterol synthesis during bioethanol production, so aeration is an important bioprocess parameter (97). S. cerevisiae does not tolerate higher sugar and salt concentrations in the medium or higher temperatures. Cane molasses media have the highest osmolarity as a consequence of medium sugar and salt concentrations, which negatively affects ethanol synthesis. Numerous studies have searched for S. cerevisiae strains with higher salt and temperature tolerance (97). Yeast Schizosaccharomyces pombe is also used in bioethanol production since it tolerates high osmotic pressures (high salt concentrations) and high solid content (97). In bioethanol production the possibility of using other microorganisms such as Zymomonas mobilis, Klebsiella oxytoca, Escherichia coli, Thermoanaerobacter ethanolicus, Pichia stipitis, Candida shehatae, Mucor indicus, etc. was also investigated (96). However, adequate alternative to $S$. cerevisiae still has not been found $(96,98)$.

The Melle-Boinot process is the typical process for bioethanol production in batch fermentation (97). It consists in broth preparation ( $\mathrm{pH}$ adjustment, $14-22 \%$ by mass) and sterilization followed by yeast fermentation. Fermented broth goes through the centrifugal separation, whereas the liquid part of the broth moves on to ethanol separation stage (usually distillation) and the yeast is recycled for the next fermentation in order to achieve higher cell concentrations (97).

Fed-batch process requires low initial substrate concentrations and yeast cells are separated from the broth which is then distilled. After bioreactor and broth preparation processes, separated yeast cells are usually used for a new fed-batch process of bioethanol production. This approach is the most common industrial technology in Brazil for bioethanol production because it can achieve the highest bioprocess volumetric productivity (97). In this bioprocess operational mode, the optimization of feeding process plays a critical role for increasing ethanol yield and productivity.

In the repeated (or multiple) batch fermentation, the use of flocculating yeast strain plays the key role (97). After initial batch process is finished, the yeast cells settle down (flocculate) on the bottom of the bioreactor and the clarified broth is removed. Subsequently, an equal amount of fresh broth is added to the bioreactor for the next batch, resulting in high cell concentrations and reduced ethanol inhibition. These batches can be repeated until the activity and viability of yeast cells is lost (due to the accumulation of yeast inhibitory compounds in broth) and consequently fresh inoculum has to be prepared for system reinoculation.

Continuous bioethanol production systems usually consist of a cascade of continuous bioreactors in which ethanol inhibition is reduced (97). This hypothesis is based on the fact that 
ethanol synthesized in the first bioreactor is easily transported to the next bioreactors and consequently ethanol inhibition is diminished. Another possibility to enhance bioprocess productivity is the continuous ethanol removal from broth during the bioprocess by using vacuum or membrane systems, but this increases capital costs (97). In continuous systems of bioethanol production increasing air supply can improve yeast cell viability, yield and concentration. Comparison between continuous and batch bioprocesses for bioethanol production shows following advantages of continuous bioprocesess: reduced costs of bioreactor constructions, lower plant maintenance and operation costs, better bioprocess control and higher productivities (97).

Most of bioethanol production plants in Brazil are still employing the fed-batch operational mode because of its practical advantages on industrial scale (97). However, $30 \%$ of industrial facilities for bioethanol production in Brazil are using continuous bioprocess systems due to their advantages related to the higher yeast cell concentrations. Immobilization, recovery and recycling of yeast cells, or control of yeast growth can increase the yeast cell density (97).

The concentration of immobilized cells in continuous bioprocesses for bioethanol production is relatively high, and at higher dilution rates bioprocess can be easily controlled, which consequently results in higher bioprocess productivities (96). Immobilization methods can be divided into following groups: (i) reversible (or irreversible) attachment to solid surfaces, (ii) entrapment in porous matrices (e.g. gelatine, agar, calcium alginate, $\mathrm{k}$-carrageenan, chitosan and polyacrylamide), (iii) mechanical separation behind a barrier (e.g. microporous membrane filters or microcapsules), and (iv) self-aggregation of the cells by flocculation (26).

Yeast cell immobilization by surface adsorption is often more efficient than entrapment or mechanical separation methods. Studies of yeast cell immobilization by the surface adsorption have shown that yeast cell growth is not significantly affected, although some yeast cells can be washed out of the system (99). The self-flocculating yeast cells showed similar bioethanol production efficiency as observed by the yeast cells immobilized on supporting materials. Furthermore, the supporting material is not used and consequently the bioprocess is simpler and economically competitive compared to the yeast cell immobilized on the supporting materials. The yeast flocs can be washed out from the bioreactor under controlled conditions in order to maintain the yeast concentration inside the bioreactor at constant level. Sedimentation or centrifugation can be used for yeast recovery after wash-out from bioreactor (99). The use of centrifugation requires higher capital investment and energy consumption costs. However, separated yeast cells can recirculate and be used in further bioethanol production cycle, and consequently bioethanol production costs are reduced.

Following bioreactor configurations were developed for the bioethanol production with self-flocculating yeast strains: airlift bioreactors, single- or two-stage packed column bioreactors, column bioreactors coupled with or without settlers, a $\mathrm{CO}_{2}$ suspended bed fermentor with baffle plates inside and separation tanks outside or only with a separation tank for $\mathrm{CO}_{2}$ separation and recycling to suspend the yeast flocs $(99,100)$.

In the last decades, very high gravity (VHG) bioethanol production technology has become attractive due to the considerable energy savings $(99,100)$. The VHG technology needs relatively high substrate ( $270 \mathrm{~g} / \mathrm{L}$ of dissolved solids or more) and final bioethanol concentration ( $15 \%$ by volume or more) in the broth. Increase of bioethanol broth concentration results in significant reduction of energy consumption for distillation and the amount of waste stillage. Therefore, this production technology is promising for industrial bioethanol production $(99,100)$.

\section{BIOETHANOL PRODUCTION FROM RAW MATERIALS THAT CONTAIN STARCH}

There are two major processes for bioethanol production from corn starch: dry-grind (67\%) and wet mill process (33 $\%$ ), both using yeasts (Saccharomyces cerevisiae, Saccharomyces pastorianus, Schizosaccaharomyces pombe and Kluyveromyces sp.) that are capable of metabolizing starch hydrolysates (5). Dry milling is often used for bioethanol production in the USA due to its lower capital and operating costs (5). In this process, the whole corn is milled (hammer or roller mill) and mixed with water to obtain a mash. The mash is cooked in a jet cooker at $80-90^{\circ} \mathrm{C}$ for $15-20 \mathrm{~min}$. During jet cooking a-amylase (relatively small amounts) is added in order to support liquefaction. Additional a-amylase is added during secondary liquefaction, which occurs for $90 \mathrm{~min}$ at $95^{\circ} \mathrm{C}$. After that, the mash is cooled to $60{ }^{\circ} \mathrm{C}$ and mixed with the glucoamylase to hydrolyse the starch into sugars which can be further metabolized to ethanol by yeast. Saccharification and fermentation often occur simultaneously (simultaneous saccharification and fermentation, SSF), thus reducing the enzyme levels and yeast cell inhibition by ethanol or substrates to minimum. The bioprocess usually takes place at $\mathrm{pH}=4.8-5.0$ and $30{ }^{\circ} \mathrm{C}$ for $48 \mathrm{~h}$ (5). The fermented broth is then distilled to produce a $95 \%$ by volume ethanol. Dehydration of the $95 \%$ by volume ethanol requires molecular sieves in order to obtain $99.5 \%$ by volume ethanol. Centrifugation of fermentation residues (whole stillage) yields wet cake, which has to be dried to obtain distiller's dried grains (DDG). Thin stillage is the liquid portion from centrifugation that has to be evaporated to obtain syrup. The syrup is then blended with DDG to form distiller's dried grains with solubles (DDGS). The residual part of the thin stillage is often recycled as process water (5).

A few modifications of dry-grind process have been introduced in order to recover corn germ or both germ and fibre before fermentation (54). Wet milling process produces various value-added co-products (e.g. fibre, germ, starch and gluten) before fermentation, which makes this process more economically feasible and energy efficient (101).

Wet milling process needs clean, steeped and degermed corn in order to obtain the germ for corn oil extraction. After that, corn is defibrated to obtain fibers, and gluten and starch are also separated. The following steps in the bioethanol production are the same as in dry-grind process: saccharification, 
fermentation, distillation and ethanol dehydration (54). Ethanol yield per kg of corn in the dry-grind process is 0.3235 and in the wet mill process 0.2919 (102).

Among SSF and SHF (separated hydrolysis and fermentation) processes that are usually used for bioethanol production from starch-containing raw materials, the technology that incorporates the yeast propagation (from active dry yeasts) in the bioreactor during initial saccharification is also applied for bioethanol production. This technology is called simultaneous saccharification, yeast propagation and fermentation (SSYPF; 103).

\section{BIOETHANOL PRODUCTION FROM RAW MATERIALS THAT CONTAIN LIGNOCELLULOSE}

There has been enormous research in the biorefining area to convert lignocellulosic raw materials into fermentable sugars. Despite huge interest and adequate progress in the lignocellulosic bioethanol research and development, many challenges still need to be solved $(26,86,104-107)$.

The most often used steps in the bioethanol production from lignocellulose-containing raw materials are: (i) pretreatment of cellulose and hemicellulose to become more accessible in the subsequent steps, (ii) acid or enzymatic hydrolysis of polysaccharides into simple sugars, (iii) microbial fermentation of the simple sugars (hexoses and pentoses) to ethanol, and (iv) separation and concentration of ethanol (97,106,107; Fig. 3).

Previous section described in detail pretreatment of lignocellulosic raw materials for their use in the bioethanol production. Therefore, in this section our focus will be on the fermentation process of lignocellulosic hydrolysates. Different microorganisms are used for fermentation of glucose to ethanol, most frequently Saccharomyces cerevisiae. It is able to metabolize mono- and disaccharides (e.g. glucose, fructose, maltose and sucrose), but not pentoses (e.g. xylose and arabinose).
Furthermore, S. cerevisiae is not capable of direct assimilation of cellulose and hemicellulose (108). The recombinant DNA technology or the pentose-fermenting microorganisms (e.g. Pichia stipitis, Pachysolen tannophilus and Candida shehatae) are used to overcome this disadvantage (109). These pentose-fermenting microorganisms have at least five times lower ethanol production rate than the ethanol production from glucose by S. cerevisiae. Moreover, oxygen and ethanol tolerance of these microorganisms are also 2-4 times lower (110). S. cerevisiae has been engineered with arabinose-metabolizing genes from yeasts such as Candida aurigiensis (111). Therefore, lately there have been many efforts to obtain an ideal microorganism that will be able to produce ethanol directly from any carbohydrate $(105,112)$.

Furthermore, ethanol-producing bacteria have also attracted attention since their growth rate is substantially higher than that of the S. cerevisiae. Z. mobilis produces ethanol from glucose via the Entner-Doudoroff pathway in conjunction with the enzymes pyruvate decarboxylase and alcohol dehydrogenase (113). It is capable of producing ethanol with efficiency up to $97 \%$ of theoretical maximum, while S. cerevisiae with efficiency around 90 to $93 \%$. However, the use of Z. mobilis is not feasible for the industrial bioethanol production because its fermentation pathways are oriented only to glucose, fructose and sucrose. Another disadvantage of the use of this bacterium is the levan formation observed during its fermentation of sugar cane syrup and other sucrose-based media. Levan is a polysaccharide that considerably increases the broth viscosity. Z. mobilis is also capable of reducing fructose into sorbitol, which additionally decreases the conversion efficiency of sucrose to ethanol (97).

On the contrary, the Gram-negative strain Zymobacter palmae is an anaerobe with a potential to metabolize hexoses, a-linked di- and trisaccharides, and sugar alcohols (fructose,

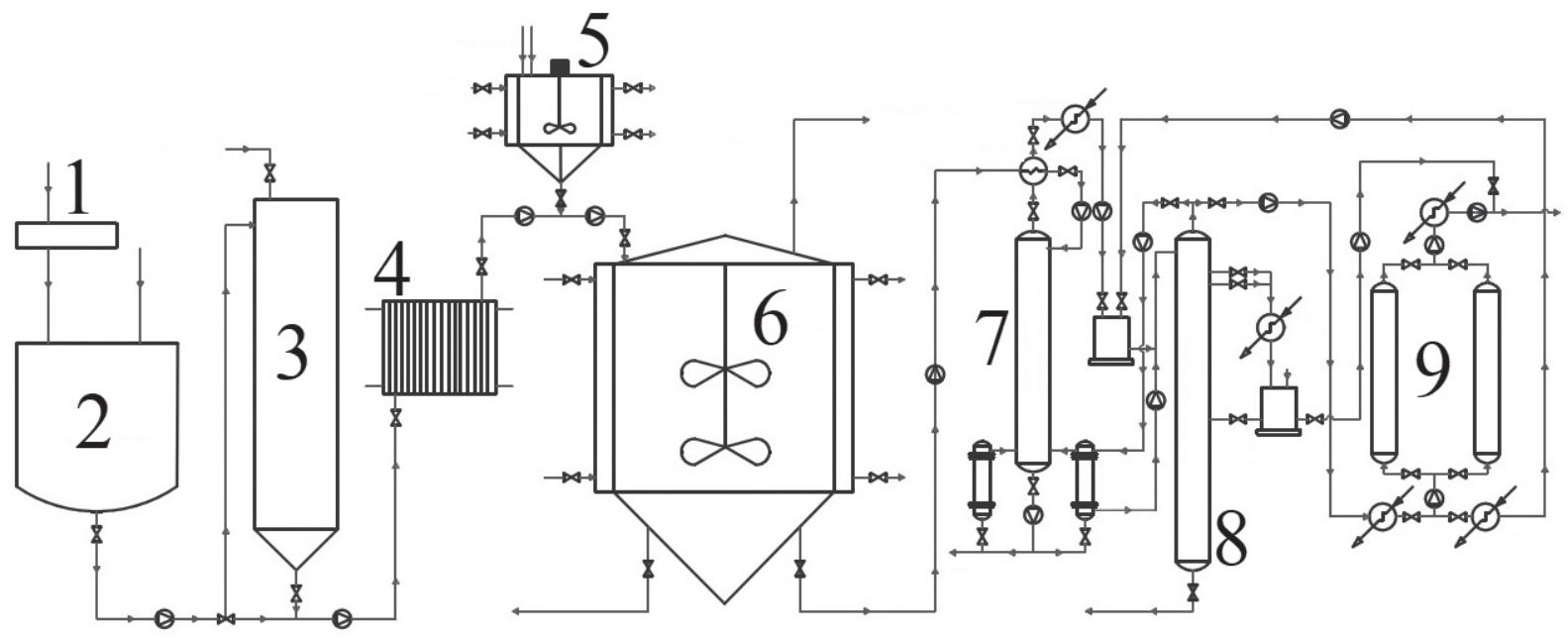

Fig. 3. The scheme of bioethanol production from lignocellulose containing raw materials. $1=$ milling, $2=$ pretreatment, $3=$ saccharification, $4=$ heat exchanger, $5=$ propagator, $6=$ bioreactor, $7=$ stripping column, $8=$ rectifying column, $9=$ molecular sieves 
galactose, glucose, mannose, maltose, melibiose, sucrose, raffinose, mannitol and sorbitol). Z. palmae produces approx. 2 mol of ethanol per mol of glucose without accumulation of byproducts, and also shows productivity similar to that of $Z$. mobilis (114).

The filamentous fungus Fusarium oxysporum is known for its ability to produce ethanol, but conversion rate is low and it produces significant acetic acid amounts as a byproduct (115). Other species, such as Neurospora, Monilia, Paecilomyces, Fusarium and Neocallimastix, have also been reported as ethanol-producing fungus (97).

In the integrated bioprocess systems, the hydrolysis and fermentation usually function as separate hydrolysis and fermentation (SHF) or simultaneous saccharification and fermentation (SSF). New integrated bioprocesses such as simultaneous saccharification and cofermentation (SSCF) and consolidated bioprocessing (CBP; 44,96) have recently emerged.

SHF hydrolyzes pretreated lignocellulosic feedstock to glucose and subsequently ferments it to ethanol in separate bioreactors (44). After pretreatment of lignocellulosic raw materials, solid phase is separated from liquid phase, which mostly contains pentose sugars and some hexoses. After pretreatment with dilute acid, residual solid phase contains mainly lignin and cellulose. Cellulose is then hydrolyzed by the addition of cellulolytic enzymes. In SHF both hydrolysis and fermentation take place at their optimal temperatures $\left(50^{\circ} \mathrm{C}\right.$ for hydrolysis and $28-32^{\circ} \mathrm{C}$ for yeast fermentation). Suitable microorganisms perform the fermentation of hexoses and pentoses separately (96). The need for separate fermentations is because pentose-utilizing microorganisms metabolize pentoses and hexoses slower than microorganisms that only assimilate hexoses. Moreover, these microorganisms are also more sensitive to ethanol and inhibitors (103). The accumulation of released sugars (mainly glucose and cellobiose) during enzymatic hydrolysis inhibits the cellulase activity. The inhibitory effect of cellobiose on cellulase is considerably higher than of glucose. At relatively low cellobiose concentrations (up to $6 \mathrm{~g} / \mathrm{L}$ ), cellulase activity is reduced by $60 \%$ compared to the production without cellobiose (116). Microbial contaminations are also a problem in the SHF because of relatively long incubation period during hydrolysis. Main contamination sources are hydrolytic enzymes, but sterilization on industrial scale is very demanding (44).

During SSF, hydrolysis and fermentation take place in a single bioreactor. Therefore, released sugars from the enzymatic hydrolysis are immediately used by the microorganism. Under these conditions, relatively low sugar concentrations are present in the broth and consequently cellulase inhibition by the released sugars is reduced (32). The optimal temperature for SSF (around $38^{\circ} \mathrm{C}$ ) is a compromise between the optimal hydrolysis $\left(45-50^{\circ} \mathrm{C}\right)$ and fermentation $\left(30^{\circ} \mathrm{C}\right)$ temperatures. Further improvement of SSF can be achieved through selection of enhanced enzymes and yeast strains (117). SSF most often uses T. reesei and S. cerevisiae. In order to use the fermentation temperature closer to the optimal hydrolysis temperature, thermotolerant yeasts and bacteria have been studied (44). According to literature, Kluyveromyces marxianus and $K$. fragilis have the highest ethanol productivity at $42^{\circ} \mathrm{C}$, when $K$. marxianus has an ethanol yield of $0.5 \mathrm{~g} / \mathrm{g}$ cellulose in $78 \mathrm{~h}$ using Solka Floc ${ }^{\circledR} 200$ (International Fiber Corporation, North Tonawanda, NY, USA) as substrate (118).

The main SSF advantages are: (i) increase of hydrolysis rate through the reduction of cellulase inhibition by released sugars, (ii) lower enzyme demand, (iii) higher bioethanol yield, (iv) lower requirement for sterile conditions, $(v)$ shorter bioprocess time, and ( $v i)$ cost reductions by elimination of expensive separation processes and equipment (44,105-107).

Main SSF disadvantages are incompatible temperatures of hydrolysis and fermentation, microbial ethanol tolerance and ethanol inhibition of enzymes (109). The incomplete substrate hydrolysis causes close association of yeast and adsorbed cellulases with fermentation residue, which prevents the recirculation of higher yeast cell concentrations required for successful bioethanol production in the next fermentation. Under these conditions, yeast cells mostly utilize sugars released from cellulose hydrolysis for growth, but not for ethanol synthesis. SSF is the operational mode of choice in many pilot-scale studies of bioethanol production despite the above-mentioned drawbacks $(44,106,107,117)$.

The inclusion of the pentose fermentation in the SSF is another promising integration alternative, and this process is called simultaneous saccharification and cofermentation (SSCF). In this mode, both producing microorganisms have to be compatible in terms of optimal $\mathrm{pH}$ and temperature. Furthermore, the development of microbial strains able to grow at elevated temperatures may significantly improve techno-economic indicators of SSCF (103). SSCF is more economically feasible, but technically much different. By cofermentation of pentoses and hexoses in one bioreactor capital costs, but also the possibility of contamination are reduced (96). In a study of Yadav et al. (119), coculture of S. cerevisiae and P. stipites resulted in conversion of both hexoses and pentoses in the hydrolysate with higher ethanol yields than the bioprocess with S. cerevisiae monoculture. Sornvoraweat et al. (120) also reported that coculture of S. cerevisiae and Candida tropicalis produced higher ethanol quantities than the S. cerevisiae monoculture by using acid hydrolysate of cassava peels. As an alternative of this configuration, Olsson and Hahn-Hägerdal (121) suggested a system including the isomerization of $x y$ lose and the fermentation with $S$. cerevisiae in a simultaneous process. In this bioprocess, glucose isomerase converts xylose into xylulose, which is subsequently utilized by yeast cells and therefore the cofermentation of lignocellulose-containing raw materials was improved. However, high byproduct $\left(\mathrm{CO}_{2}\right.$ and xylitol) synthesis, poor enzyme stability, incompatible $\mathrm{pH}$ and temperature, and the reversibility of the enzyme transformation are the main drawbacks of this bioprocess (122).

Another integration approach for the conversion of lignocellulose-containing raw materials into bioethanol is the consolidated bioprocessing (CBP; 103). In this approach, cellulase production and fermentation require only one microorganism. 
Therefore, cellulase production, cellulose hydrolysis and fermentation are performed in a single step. Actually, the concept of CBP involves four biological reactions in one step: the production of enzymes (cellulases and hemicellulases), carbohydrate hydrolysis into sugars, fermentation of hexoses (glucose, mannose and galactose), and fermentation of pentoses (xylose and arabinose). The CBP has the following advantages compared to the other integrated systems for bioethanol production: the enzymatic and fermentation systems are completely compatible and therefore costs of bioethanol production are reduced, capital and operation investments are not required and part of the substrate is not spent for cellulase production (103). In CBP, usually Clostridium thermocellum is used for enzyme production, cellulose hydrolysis and glucose fermentation, where $C$. thermosaccharolyticum coferments pentoses (obtained from hemicellulose) into ethanol (103). The CBP system with C. thermosaccharolyticum shows $31 \%$ higher substrate conversion than the CBP system with Trichoderma reesei and S. cerevisiae. However, the main problems of this CBP system are still not adequately solved such as: ethanol yield reduction due to the formation of acetic and other organic acid salts (e.g. lactate) and low ethanol tolerance by Clostridia $(103,117)$. Although CBP is interesting from economic point of view, until now, an effective microorganism that exhibits all required features has still not been found. However, genetic engineering could improve the properties of microorganisms that are already being applied in the ethanol fermentation. Microorganisms with high cellulase activity need to have enhanced fermentation properties, and contrary, microorganisms with satisfactory fermentation properties need to have cellulolytic and/or hemicellulolytic activity (96). For example, improved recombinant strain of $C$. thermocellum produces 60 $\mathrm{g} / \mathrm{L}$ of ethanol. Also, the use of genetic engineering improved cellulolytic activity of highly productive recombinant strains of bacteria E. coli, K. oxytoca and Z. mobilis, and yeast S. cerevisiae (123). Sakamoto et al. (124) constructed a recombinant Saccharomyces cerevisiae that is able to hydrolize hemicelluloses with endoxylanase from T. reesei, $\beta$-xylosidase from Aspergillus oryzae, and $\beta$-glucosidase from Aspergillus aculeatus, as well as to assimilate xylose through the expression of xylose reductase and xylitol dehydrogenase from $P$. stipitis and xylulokinase from S. cerevisiae. This recombinant strain successfully produces bioethanol from rice straw hydrolysate, without requiring the addition of sugar-hydrolyzing enzymes or detoxication. Authors confirmed that such cell surface-engineered strain can be highly effective in consolidating bioethanol production from hemicellulosic raw materials.

Moreover, Ishola et al. (125) developed and evaluated a novel method of lignocellulosic bioethanol production, simultaneous saccharification, filtration and fermentation (SSFF). SSFF is an integrated bioprocess that allows simultaneous enzymatic hydrolysis of lignocellulosic biomass, filtration of sugars from hydrolysis and filtrate fermentation with yeast Saccharomyces cerevisiae. In SSFF, pretreated lignocellulose-containing raw material is enzymatically hydrolyzed in a bioreactor, while the suspension is continuously pumped through a cross-flow membrane. The retentate goes back to the bioreactor for hydrolysis and purified sugar-rich filtrate is continuously added to the bioreactor for fermentation. The membrane (module made of polyethylene with a polypropylene housing used in a cross-flow microfiltration) was able to filter pretreated spruce slurry up to $14.4 \%$ per mass suspended solids, without clogging and it worked continuously for 28 days. The flocculating strain of S. cerevisiae was succesfully reused for 5 different batches of SSFF, and its cultivations resulted in an ethanol yield of up to $85.0 \%$ of the theoretical yield. Ishola et al. (126) also used SSFF system for simultaneous glucose and xylose uptake by genetically modified yeast strain S. cerevisiae (T0936) with the ability to ferment xylose in the bioethanol production from pretreated wheat straw (xylose-rich lignocellulose-containing raw material). In this SSFF ethanol yield was $90 \%$ of the theoretical yield.

Some examples of bioprocess operational modes for bioethanol production from various lignocellulosic raw materials are presented in Table 2 (127-133).

\section{BIOETHANOL SEPARATION AND PURIFICATION}

Two energy-demanding separation steps are necessary to obtain purified ethanol ( $95.63 \%$ by mass) from binary azeotrope ethanol-water (54). The first step is a standard distillation that concentrates ethanol up to the level of $92.4-94 \%$ by mass. The cyclic distillation for ethanol purification is an energy-efficient alternative that is characterised by relatively low investments. The second step involves ethanol dehydration to obtain an anhydrous ethanol (ethanol concentrations above the azeotropic composition). Several well known methods serve that purpose, such as pressure-swing distillation $(134,135)$, extractive distillation (with liquid solvent, dissolved salt, their mixture, ionic liquids, hyperbranched polymers; 136-139), azeotropic distillation $(140,141)$ and combination of these methods. The distillation residue is called vinasse and it could be an environmental problem because $1 \mathrm{~L}$ of ethanol generates around $15 \mathrm{~L}$ of vinasse (38).

In the next paragraphs we will discuss innovative techniques. In order to reduce energy consumption of conventional distillation, membrane techniques have gained attention as an alternative because of a number of advantages that make them attractive for the separation of liquid mixtures. They have high separation efficiency, energy and operating costs are relatively low, they produce no waste streams, and they can be used in the separation of temperature-sensitive materials (142-145). Among the available membrane techniques, pervaporation is quite attractive due to its simplicity, low energy-demands and the absence of extra chemicals; besides, the vacuum part of the process consumes the majority of energy (54). It uses a non-porous membrane which separates the mixture as a result of molecular interactions between the feed components and the membrane. The transport of molecules through the membrane generally involves three steps: (i) molecules from the feed are selectively adsorbed into the 
Table 2. Different bioprocess operational modes for bioethanol production from various lignocellulosic raw materials

\begin{tabular}{|c|c|c|c|c|c|c|c|c|}
\hline Feedstock & $\begin{array}{l}\text { Pretreatment/ } \\
\text { hydrolysis }\end{array}$ & Microorganism & $\begin{array}{l}\text { Bioprocess } \\
\text { mode }\end{array}$ & $\frac{\gamma(\text { ethanol })}{\mathrm{g} / \mathrm{L}}$ & $\begin{array}{c}E \\
\%\end{array}$ & $\frac{P_{\max }}{\mathrm{g} /(\mathrm{L} \cdot \mathrm{h})}$ & $\begin{array}{l}\text { Note } \\
\text { (optimized } \\
\text { conditions) }\end{array}$ & Reference \\
\hline $\begin{array}{l}\text { Sugar cane } \\
\text { bagasse }\end{array}$ & $\begin{array}{l}\text { Diluted acid }\left(\mathrm{H}_{2} \mathrm{SO}_{4}\right) \\
\text { followed by alkaline } \\
\text { delignification }(\mathrm{NaOH}) \text {, } \\
\text { cellulase complex } \\
\text { obtained from } \\
\text { Trichoderma reesei } \\
\left(\text { MULTIFECT }^{\circledR}\right)\end{array}$ & $\begin{array}{l}\text { Recombinant } \\
\text { Saccharomyces } \\
\text { cerevisiae containing } \\
\text { the } \beta \text { - } \\
\text { glucosidase gene from } \\
\text { Humicola grisea }\end{array}$ & Batch SSF & 51.7 & - & 0.94 & - & $(127)$ \\
\hline Bagasse & $\begin{array}{l}\text { Acid }\left(\mathrm{H}_{3} \mathrm{PO}_{4}\right) \\
\text { Accellerase } \\
1500 \text { enzyme }\end{array}$ & $\begin{array}{l}\text { Z. mobilis ATCC } 29191 \\
\text { immobilized in } \\
\text { Ca-alginate } \\
\text { (CA) and polyvinyl } \\
\text { alcohol (PVA) gel beads }\end{array}$ & SSF & $\begin{array}{l}6.24 \\
5.52 \\
5.53 \\
5.44\end{array}$ & $\begin{array}{l}79.09 \\
69.96 \\
70.09 \\
68.95\end{array}$ & $\begin{array}{l}1.31 \\
1.27\end{array}$ & $\begin{array}{l}\text { PVA } \\
\text { CA } \\
\text { PVA } \\
\text { CA }\end{array}$ & $(128)$ \\
\hline $\begin{array}{l}\text { Eucalyptus } \\
\text { globulus } \\
\text { wood }\end{array}$ & $\begin{array}{l}\text { Organosolv } \\
(50 \% \mathrm{EtOH}, \\
\left.200^{\circ} \mathrm{C}, 45 \mathrm{~min}\right), \\
\text { cellulase (Celluclast) } \\
\text { and } \beta \text {-glucosidase } \\
\text { (Novozym 188) }\end{array}$ & S. cerevisiae IR2T9-a & SSF & $\sim 42$ & - & - & $\begin{array}{l}\text { substrate } \\
\text { loading } 15 \% \text {, } \\
\text { enzyme loading } \\
\text { of } 20 \mathrm{FPU} \\
\text { cellulose and } 40 \\
\text { UI } \beta \text {-glucosidase } \\
\gamma(\mathrm{strain})=6 \text { and } \\
12 \mathrm{~g} / \mathrm{L}\end{array}$ & (129) \\
\hline Rice straw & $\begin{array}{l}\text { Alkali }(\mathrm{NaOH}), \\
\text { Accellerase }^{\circledR} \\
1500 \text { enzyme }\end{array}$ & $\begin{array}{l}\text { S. cerevisiae, } \\
\text { Candida } \\
\text { tropicalis, } \\
\text { S. stipitis }\end{array}$ & Batch SSCF & 28.6 & 86 & - & $\begin{array}{l}\text { S. cerevisiae/ } \\
\text { S. stipitis cell } \\
\text { ratio of } 0.31 \text {, } \\
\text { agitation } \\
\text { rate } 116 \text { rpm, } \\
\text { temperature } \\
33.1^{\circ} \mathrm{C}\end{array}$ & $(130)$ \\
\hline Corn stover & $\begin{array}{l}\text { AFEX } \\
\text { commercial enzymes } \\
\text { mixture (Ctec 2, } \\
\text { Htec } 2 \text { and Multifect } \\
\text { pectinase) }\end{array}$ & $\begin{array}{l}\text { Genetically engineered } \\
\text { S. cerevisiae Y } 35\end{array}$ & $\begin{array}{l}\text { SHF } \\
\text { SSCF }\end{array}$ & $\begin{array}{l}45.5 \\
51.3\end{array}$ & - & 0.76 & $\begin{array}{l}30^{\circ} \mathrm{C} \\
9 \% \text { glucan } \\
\text { loading (GL) } \\
35^{\circ} \mathrm{C} \\
9 \% \mathrm{GL}\end{array}$ & $(131)$ \\
\hline $\begin{array}{l}\text { Cellulosic } \\
\text { material, } \\
\beta \text {-glucan }\end{array}$ & - & $\begin{array}{l}\text { Recombinant } \\
\text { Kluyveromyces } \\
\text { marxianus K1 }\end{array}$ & CBP & 4.24 & 92.2 & 0.55 & $48^{\circ} \mathrm{C}$ & $(132)$ \\
\hline Corn stover & AFEX & $\begin{array}{l}\text { Clostridium } \\
\text { phytofermentans (ATCC } \\
700394 \text { ) }\end{array}$ & CBP & 7.0 & - & - & $\begin{array}{l}4 \% \mathrm{GL}, \\
\text { no nutrient } \\
\text { supplementation }\end{array}$ & (133) \\
\hline
\end{tabular}

$E=$ bioprocess effieciency $\left(E=Y_{\mathrm{P} / \mathrm{S}} / Y_{\mathrm{P} / \mathrm{ST}} \cdot 100 ; Y_{\mathrm{P} / \mathrm{S}}=\right.$ conversion coefficient of substrate into ethanol $\left(\mathrm{g} \mathrm{C} \mathrm{H}_{5} \mathrm{OH} / \mathrm{g} \mathrm{sugar}\right), Y_{\mathrm{P} / \mathrm{ST}}=$ theoretical conversion coefficient of substrate into ethanol ( $\mathrm{g} \mathrm{C}_{2} \mathrm{H}_{5} \mathrm{OH} / \mathrm{g}$ sugar)), $P_{\max }=$ maximal ethanol productivity in bioprocess

membrane, (ii) diffusion of the adsorbed molecules across the membrane, and (iii) desorption of the molecules into the gas phase on the permeate side. Polymeric membranes which can be used in the ethanol separation from the fermentation broth include polydimethylsiloxane (the most commonly used because of its good selectivity and stability) and poly-1-(trimethylsilyl)-1-propyne membranes, polyether block amide membranes, other modified polymeric membranes, porous polypropylene and polytetrafluoroethylene membranes (146149). Besides the above mentioned, inorganic hydrophobic zeolite membranes can also be used (150). Furthermore, two types of hydrophobic zein (monolayer and composite) membranes were also studied for ethanol separation (151).

Pervaporation can be carried out in parallel to the fermentation. This is promising system for in situ extraction of ethanol, which is harmless to the working microorganism (152). Therefore, low ethanol medium concentrations can prevent ethanol inhibition, and consequently the bioprocess can run continuously. Before the pervaporation unit, a microfiltration/ ultrafiltration module has to be installed for biomass removal to prevent deterioration of the pervaporation membrane. This integrated system was used in the study of ethanol separation from aqueous solution and fermented sorghum juice (152). Cost analysis of the separation from the fermented juice showed it is higher than in some other methods, therefore it is necessary to optimize the procedure.

The silicalite-1/polydimethylsiloxane/polyvinylidene fluoride hybrid composite membrane was used for the in situ extraction of ethanol during the fermentation of sorghum juice in a fed-batch and a continuous bioprocess (153). The results of this study show that the integration of bioprocess considerably improves the bioprocess productivity and ethanol separation efficiency. The nanocomposite membrane made of polyamides with integrated carbon nanotubes was also used for ethanol separation (154). The results show that the membrane is most effective when used for the separation of mixtures with an ethanol content of more than $50 \%$ by mass. The temperature of the mixture also plays a significant role; at higher 
temperatures, there is an increase in the permeate flux, but the separation factor decreases.

Liquid-liquid extraction is another attractive method for ethanol separation from fermentation broth (155). The process involves the direct contact of a water-insoluble solvent with the broth in the bioreactor or in an externally located extraction vessel. During the contact, ethanol diffuses from the broth and is dissolved in the solvent, after which it needs to be isolated from the solvent with distillation or re-extraction using acid or base solutions. The selected solvent must meet some criteria, such as satisfactory extraction efficien$c y$, chemical stability, water insolubility, must not form foam or emulsion, must be nontoxic, environmentally friendly and affordable. The most attractive solvents are ketones, esters and alcohols due to their low reactivity and high distribution coefficients (ketones $0.13-0.79$, alcohols $0.53-1.30$ and esters 0.24-0.59). Most of the interesting solvents were discarded because of their toxicity to the working microorganisms. The toxicity problem could be solved by using natural organic compounds, such as fatty acids, $\beta$-alcohols and carboxylic acids (155). Therefore, several fatty acids as solvents for ethanol extraction from water were examined (156). Valeric acid, a low-molecular-mass fatty acid, extracted the highest amount of ethanol, but alongside, it extracted water and it is partly soluble in it. The same was reported for other low-molecular mass fatty acids (156). Oleic acid is insoluble in water, but it extracted a small quantity of ethanol. Octanoic and nonanoic acid proved to be the best; however, nonanoic acid was the most suitable solvent because of its minimal evaporation during flash distillation, which resulted in a gaseous mixture with $69.5 \%$ ethanol. This method requires $38 \%$ less energy for the same amount of ethanol than fractional distillation (156).

The efficiency of ethanol extraction using vegetable oils, such as coconut, olive, safflower and castor oil, and their derivatives, alcohols and esters was also examined (157). These oils were compared with the following esters: methyl laurate, methyl oleate, methyl linoleate, and methyl ricinoleate, and alcohols: lauryl (1-dodecanol), oleyl and ricinoleyl. Out of these compounds, castor oil, ricinoleyl alcohol and methyl ricinoleate showed higher ethanol distribution coefficients with similar or slightly lower separation factors than other compounds used in this study. It is interesting that ricinoleyl alcohol has a $50 \%$ higher distribution coefficient than oleyl alcohol, the most commonly used alcohol in ethanol extraction from fermentation broth. The use of higher $\beta$-branched alcohols, and their analogues in the form of carboxylic acids was also studied (158). The results showed that the C14-C20 $\beta$-branched alcohols have a narrow range of distribution coefficients (0.2-0.3), but a wide value range of separation factors, which reflects the influence of the position of hydroxyl groups and branching. Due to the low distribution coefficient values, the use of such alcohols is not recommended, but due to their non-toxicity and low solubility in the raffinate, as compared with shorter chain alcohols, it is possible to select and define the conditions of their application. Comparing the results of that study with the results obtained for carboxylic acids (C8-C18), it is obvious that acids have higher separation factors, and lower distribution coefficient values (159). Although it is preferable to use acids with shorter chains with higher distribution coefficients, their solubility in water and toxicity on the working micoorganisms prevents it. It is therefore advisable to use C16-C18 fatty acids as they are less soluble in the raffinate, are non-toxic and non-inhibitory.

Gas stripping is another alternative to distillation for the extraction of volatile components, such as ethanol, from fermentation broth (160-162). The process is relatively simple, does not require expensive equipment, fermentation culture is not harmed, it does not remove nutrients from the broth, it reduces product inhibition and it can be used for in situ separation of the desired product. In this method, inert gas is sparged through the broth. By passing through the broth, it collects volatile components. The most suitable gas is $\mathrm{CO}_{2}$, as it is one of the fermentation products, but other gases $\left(\mathrm{N}_{2}\right.$ or $\mathrm{H}_{2}$ ) and air can also be used (163). After passing through the bioreactor, the outflow is cooled in a condenser in order to condensate the desired products. Besides condensation, other methods can also be used, such as membrane separation and extraction $(160,164-166)$. The gas is then recycled by going through another cycle of stripping. In most cases, the alcohol-rich condensate must pass through at least one purification step to remove excess water. Research results show that by using gas stripping, higher ethanol yield and productivity can be achieved.

Several studies of ethanol separation by gas stripping from fermentation broth during continuous bioprocess were conducted $(167,168)$. These studies examined the effect of ethanol concentration on working microorganism and bioprocess productivity. The pilot plant consisted of a 14-litre bioreactor and a 10-cm column, and the bioprocess was continuously run for over 100 days. The feed contained $560 \mathrm{~g} / \mathrm{L}$ glucose and $100 \mathrm{~g} / \mathrm{L}$ corn steep water. $\mathrm{CO}_{2}$ produced by fermentation was used as the stripping gas. The productivity of the process varied between 14 and $17 \mathrm{~g} /(\mathrm{L} \cdot \mathrm{h})$. In a similar study (169), a pilot plant with a fermentor of $30 \mathrm{~L}$ was run for 185 days. The yield was slightly lower than the maximum theoretically possible $(0.50 \mathrm{~g} / \mathrm{g})$, which resulted in an average bioprocess productivity of 7.5-12.6 g/(L.h). In both studies growth inhibition occurred when the broth ethanol concentration was higher than $65 \mathrm{~g} / \mathrm{L}$. Chen et al. (170) compared ethanol production from sorghum with or without gas stripping. Fermentation with gas $\left(\mathrm{CO}_{2}\right)$ stripping proved to be a better choice for ethanol production, because the yield was $0.227 \mathrm{~g} / \mathrm{g}$ with a stripping efficiency of $77.5 \%$. Temperature is one of the most important parameters in the fermentation and stripping processes. With the increase in temperature, stripping efficiency increases. The highest ethanol extraction efficiency of $96.4 \%$ was at $75{ }^{\circ} \mathrm{C}$, but this temperature has a negative effect on microorganism growth, and increases the energy costs. It is therefore necessary to adjust the stripping temperature to the microorganism, or use 
heat-resistant microorganisms while keeping in mind that fermentation temperature should not be higher than $40^{\circ} \mathrm{C}$. It was also observed that the gas bubble size has an influence on the efficiency of stripping. By reducing the bubble size from $0.4 \mathrm{~cm}$ to $0.05 \mathrm{~cm}$, an increase of $30 \%$ in efficiency was observed. Ponce et al. (171) assessed an integrated fermentation stripping system for ethanol production. In that research, $58 \%$ of total ethanol in the broth was continuously withdrawn from the bioreactor. Although the removal of ethanol was not complete, the percentage that was removed was sufficient for ethanol concentration to drop below the inhibitory values. Lower condensation temperatures have a negative impact on the ethanol concentration in the condensate. The most interesting temperatures are in the range of -2 to $-5^{\circ} \mathrm{C}$ because at these temperatures a significant amount of ethanol was obtained. As for the gas flow, it was concluded that higher flow rates encourage better ethanol separation from the system and therefore increase the overall bioprocess efficiency.

Adsorption is a separation technique in which molecules of gas or solution components are adsorbed on the solid surface (adsorbent). The adsorbent is a stable crystalline solid having negligible or no solubility in water or alcohol. Substances are adsorbed onto it depending on their physical and chemical properties. Generally, larger particles are more easily adsorbed due to their low diffusivity. Adsorbents are usually located in column devices. Unlike systems with gaseous or liquid extractants, the solid adsorbent does not move through the system. Therefore, adsorption involves two phases, the loading phase (adsorption) and the discharge phase (desorption). Similar to liquid extractants, a solid adsorbent has a specific selectivity and sorption distribution coefficients for water and ethanol. The most studied class of alcohol-selective adsorbents are hydrophobic zeolites, in particular zeolites with a ZSM-5 structure and various silicon and aluminium ratios (172-174). The most important zeolite of this type is silicalite-1, which does not contain aluminium. Other adsorbents that have been studied are polymeric resins, polyvinylpyridine $(173)$, activated carbon $(173,174)$ and activated carbon molecular sieves (175). Studies conducted with silicalite-1 showed that water and ethanol compete for sorption sites on the adsorbent. When pure water was used, silicalite-1 adsorbed $40 \mathrm{mg} / \mathrm{g}$ water, whereas when a mixture containing ethanol and water was used, there was a decrease in the adsorption of water. At $5 \%$ by mass ethanol, about 85 to $100 \mathrm{mg} / \mathrm{g}$ ethanol was adsorbed onto the surface, and only about $20 \mathrm{mg} / \mathrm{g}$ water, which is equal to a separation factor of 76 (174).

For ethanol recovery from fermentation broth, silicalite-1, ZSM-5 and activated carbon molecular sieves (CMS-5A) were also examined as adsorbents (176). ZSM-5 adsorbed $0.068 \mathrm{~g} / \mathrm{g}$ ethanol, silicalite- $10.084 \mathrm{~g} / \mathrm{g}$ and CMS-5A $0.126 \mathrm{~g} / \mathrm{g}$. Silicalite and ZSM-5 did not adsorb measurable quantities of glucose, fructose and glycerol, while CMS-5A adsorbed 0.011 $\mathrm{g} / \mathrm{g}$ glucose, $0.010 \mathrm{~g} / \mathrm{g}$ fructose, and $0.014 \mathrm{~g} / \mathrm{g}$ glycerol. The measurement of ethanol adsorption from broth showed that it decreased only slightly, while there was a notable reduction in sugar and glycerol adsorption (176). In a recent study, activated carbon as an adsorbent for ethanol separation from fermentation broth was studied (177). They used two separation modes; in the first activated carbon was added directly into the broth, while in the second it was placed in an external container through which the broth circulated at specific time intervals. The second method proved to be much more efficient with final ethanol concentration of $51 \mathrm{~g} / \mathrm{L}$.

The new adsorption process that uses activated molecular sieving carbon (MSC) was also studied (175). The pore diameter of the sieves was around the size of an ethanol molecule. Experiments were conducted using five different MSCs, which were compared with two hydrophobic zeolites, and one hydrophilic zeolite adsorber. The total pore adsorption capacity of the MSCs was $0.2 \mathrm{~mL} / \mathrm{g}$. The most promising adsorbent was MSC4A, which, after adsorption and desorption at temperatures higher than $100{ }^{\circ} \mathrm{C}$, helped to obtain a mixture with $96 \%$ by volume ethanol (175).

On the basis of previous discussion, it is obvious that the majority of studies still use two-component ethanol and water solutions, without taking into account other substances present in the fermentation broth. It is therefore necessary to conduct further research in order to check the influence of other components on adsorption, or to investigate other methods that can be coupled with adsorption to facilitate the separation and purification of ethanol. Some of the methods that can be used with adsorption are ozonation $(178,179)$ or gas stripping $(180,181)$.

\section{CONCLUSIONS}

Based on the presented data, it is obvious that bioethanol can be an alternative solution for the current fuel issue. There has been significant progress in renewable biomass pretreatment, cellulase production and cofermentation of sugars (pentose and hexose) as well as bioethanol separation and purification in recent decades, but bioethanol (based on the production costs) is still not competitive (exception can be only bioethanol production from sugar cane in Brazil) to the fossil fuels. The biggest challenge remains how to reduce the production cost of bioethanol. Therefore, the biorefinery concept is needed to utilize renewable feedstocks more comprehensively and to manufacture more value-added coproducts (e.g. bio-based materials from the lignin) that would reduce the cost of bioethanol production. This will make bioethanol more economically competitive than the fossil fuels.

\section{ACKNOWLEDGMENTS}

This work received support by the project Phoenix (H2020-MSCA-RISE project No. 690925) and the project "Sustainable production of bioethanol and biochemicals from agricultural waste lignocelullosic raw materials" (Croatian Science Foundation No. 9158). 


\section{REFERENCES}

1. Bhaskar T, Bhavya B, Singh R, Naik DV, Kumar A, Goyal HB. Thermochemical conversion of biomass to biofuels. In: Pandey A, Larroche C, Ricke SC, Dussap CG, Gnansounou E, editors. Biofuels - Alternative feedstocks and conversion processes. Oxford, UK: Academic Press; 2011. pp. 51-77. https://doi.org/10.1016/B978-0-12-385099-7.00003-6

2. Forster P, Ramaswamy V, Artaxo P, Berntsen T, Betts R, Fahey DW, et al. Changes in atmospheric constituents and in radiative forcing. In: Solomon S, Qin D, Manning M, Chen Z, Marquis M, Averyt KB, et al., editors. Climate change 2007: The physical science basis. Cambridge, UK: Cambridge University Press; 2007, pp. 129-234.

3. Cherubini F, Strømman AH. Principles of biorefining. In: Pandey A, Larroche C, Ricke SC, Dussap CG, Gnansounou E, editors. Biofuels - Alternative feedstocks and conversion processes. Oxford, UK: Academic Press; 2011. pp 3-24. https://doi.org/10.1016/B978-0-12-385099-7.00001-2

4. Lange JP. Lignocellulose conversion: An introduction to chemistry, process and economics. Biofuels Bioprod Bior. 2007;1(1):39-48. https://doi.org/10.1002/bbb.7

5. Khanal SK. Anaerobic biotechnology for bioenergy production: Principles and applications. Ames, IA, USA:Wiley-Blackwell; 2008.

https://doi.org/10.1002/9780813804545

6. Yüksel F, Yüksel B. The use of ethanol-gasoline blend as a fuel in an SI engine. Renew Energ. 2004;29(7):1181-91. https://doi.org/10.1016/j.renene.2003.11.012

7. World Bioenergy Association. WBA Global Bioenergy Statistics; 2017. Available from: www.worldbioenergy.org/global-bioenergy-statistics.

8. Biorefineries Roadmap, German Federal Government action plans for the material and energetic utilisation of renewable raw materials. 2012. Available from: https://www. bmbf.de/pub/Roadmap_Biorefineries_eng.pdf.

9. Kamm B, Kamm M, Gruber PR, Kromus S. Biorefinery systems - An overview. In: Kamm B, Gruber PR, Kamm M, editors. Biorefineries - Industrial processes and products: Status quo and future directions. Weinheim, Germany: Wiley-VCH Verlag GmbH; 2008. pp. 1-40. https://doi.org/10.1002/9783527619849

10. Cherubini F. The biorefinery concept: Using biomass instead of oil for producing energy and chemicals. Energ Convers Manage. 2010;51(7):1412-21.

https://doi.org/10.1016/j.enconman.2010.01.015

11. Grilc M, Likozar B. Levulinic acid hydrodeoxygenation, decarboxylation and oligmerization over $\mathrm{NiMo} / \mathrm{Al} 2 \mathrm{O} 3$ catalyst to bio-based value-added chemicals: Modelling of mass transfer, thermodynamics and micro-kinetics. Chem Eng J. 2017;330:383-97.

https://doi.org/10.1016/j.cej.2017.07.145
12. Huš M, Bjelić A, Grilc M, Likozar B. First-principles mechanistic study of ring hydrogenation and deoxygenation reactions of eugenol over Ru(0001) catalysts. J Catal 2018;358:8-18.

https://doi.org/10.1016/j.jcat.2017.11.020

13. Bjelić A, Grilc M, Likozar B. Catalytic hydrogenation and hydrodeoxygenation of lignin-derived model compound eugenol over $\mathrm{Ru} / \mathrm{C}$ : Intrinsic microkinetics and transport phenomena. Chem Eng J. 2018;333:240-59.

https://doi.org/10.1016/j.cej.2017.09.135

14. Kromus S, Wachter B, Koschuh W, Mandl M, Krotscheck C, Narodoslawsky M. The green biorefinery Austria - Development of an integrated system for green biomass utilization. Chem Biochem Eng Q. 2004;18(1):7-12.

15. Koller M, Bona R, Hermann C, Horvat P, Martinz J, Neto J, et al. Biotechnological production of poly(3-hydroxybutyrate) with Wautersia eutropha by application of green grass juice and silage juice as additional complex substrates. Biocatal Biotransformation. 2005;23(5):329-37. https://doi.org/10.1080/10242420500292252

16. Khuong LS, Masjuki HH, Zulkifli NWM, Niza Mohamad E, Kalam MA, Alabdulkarem A, et al. Effect of gasoline-bioethanol blends on the properties and lubrication characteristics of commercial engine oil. RSC Adv. 2017;7(25):15005-19.

https://doi.org/10.1039/C7RA00357A

17. OECD/Food and Agriculture Organization of the United Nations. OECD-FAO Agricultural Outlook 2015. Paris, France: OECD Publishing; 2015.

https://doi.org/1787/agr_outlook-2015-en

18. European Biofuels Technology Platform. Strategic research agenda 2010 update: Innovation driving sustainable biofuels. 2010. Available from: http://www.biofuelstp.eu/srasdd/ SRA_2010_update_web.pdf.

19. van Thuijl E, Deurwaarder EP. European biofuels policies in retrospect. Petten, the Netherlands: Energy Research Centre of the Netherlands (ECN); 2006. Available from: https:// www.ecn.nl/publications/PdfTetch.aspx?nr=ECN-C-06-016.

20. Prieur-Vernat A, His S, Biofuels worldwide. Panorama 2007. Rueil-Malmaison, France: IFP-Innovation Energy Einveroment; 2007. Available from: http://www.firp.ula.ve/archivos/material_web_4xx/07_IFP_Biofuels.pdf.

21. Li K, Liu S, Liu X. An overview of algae bioethanol production. Int J Energ Res. 2014;38(8):965-77.

https://doi.org/10.1002/er.3164

22. Balat $M$, Balat $H$. Recent trends in global production and utilization of bio-ethanol fuel. Appl Energy. 2009;86(11):2273-82. https://doi.org/10.1016/j.apenergy.2009.03.015

23. Festel G, Würmseher M, Rammer C, Boles E, Bellof M. Modelling production cost scenarios for biofuels and fossil fuels in Europe. Discussion paper No. 13-075. Mannheim, Germany: ZEW - Centre for European Economic Research; 2013. Available from: http://ftp.zew.de/pub/zew-docs/dp/ dp13075.pdf. 
24. Zhao L, Zhang X, Xu J, Ou X, Chang S, Wu M. Techno-economic analysis of bioethanol production from lignocellulosic biomass in China: Dilute-acid pretreatment and enzymatic hydrolysis of corn stover. Energies. 2015;8(5):4096-117. https://doi.org/10.3390/en8054096

25. What determines retail prices for gasoline and diesel? Plymouth, MA, USA:Volta Oil; 2018. Available from: http://www. voltaoil.com/what-makes-up-retail-price-for-gasoline/.

26. Mussatto SI, Dragone G, Guimarães PMR, Silva JPA, Carneiro LM, Roberto IC, et al. Technological trends, global market, and challenges of bio-ethanol production. Biotechnol Adv. 2010;28(6):817-30.

https://doi.org/10.1016/j.biotechadv.2010.07.001

27. Tomás-Pejó E, Alvira P, Ballesteros M, Negro MJ. Pretreatment technologies for lignocellulose-to-bioethanol conversion. In: Pandey A, Larroche C, Ricke SC, Dussap CG, Gnansounou E, editors. Biofuels - Alternative feedstocks and conversion processes. Oxford, UK: Academic Press; 2011. pp. 149-76. https://doi.org/10.1016/B978-0-12-385099-7.00007-3

28. Linoj KNV, Dhavala P, Goswami A, Maithel S. Liquid biofuels in South Asia: Resources and technologies. Asian Biotechnol Develop Rev. 2006;8(2):31-49.

29. İçöz E, Tuğrul KM, Saral A, İçöz E. Research on ethanol production and use from sugar beet in Turkey. Biomass Bioenergy. 2009;33(1):1-7.

https://doi.org/10.1016/j.biombioe.2008.05.005

30. Tabak J. Biofuels. New York, NY, USA: Infobase Publishing; 2009.

31. Pavlečić $M$, Vrana I, Vibovec $K$, Ivančić Šantek $M$, Horvat $P$, Šantek B. Ethanol production from different intermediates of sugar beet processing. Food Technol Biotechnol. 2010; 48(3):362-7.

32. Pavlečić $M$, Rezić $T$, Ivančić Šantek $M$, Horvat $P$, Šantek $B$. Bioethanol production from raw sugar beet cossettes in horizontal rotating tubular bioreactor, Bioprocess Biosyst Eng. 2017;40(11):1679-88.

https://doi.org/10.1007/s00449-017-1823-x

33. Senthilkumar V, Gunasekaran P. Bioethanol from biomass production of ethanol from molasses. In: Pandey A, editor. Handbook of plant-based biofuels. Boca Raton, FL, USA: CRC Press; 2009. pp. 73-86.

34. Ling KC. Whey to ethanol: A biofuel role for dairy cooperatives? USDA Rural Development: Research Report 214. 2008. Available from: http://www.rd.usda.gov/files/RR214. pdf.

35. Jobling S. Improving starch for food and industrial applications. Curr Opin Plant Biol. 2004;7(2):210-8. https://doi.org/10.1016/j.pbi.2003.12.001

36. Solomon BD, Barnes JR, Halvorsen KE. Grain and cellulosic ethanol: History, economics, and energy policy. Biomass Bioenergy. 2007;31(6):416-25.

https://doi.org/10.1016/j.biombioe.2007.01.023
37. Mousdale DM, Biofuels: Biotechnology, chemistry and sustainable development. Boca Raton, FL, USA: CRC Press; 2008.

38. Soccol CR, Faraco V, Karp S, Vandenberghe LPS, Thomaz-Soccol V, Woiciechowski A, Pandey A. Lignocellulosic bioethanol: Current status and future perspectives. In: Pandey A, Larroche C, Ricke SC, Dussap CG, Gnansounou E, editors. Biofuels - Alternative feedstocks and conversion processes. Oxford, UK: Academic Press; 2011. pp. 101-22. https://doi.org/10.1016/B978-0-12-385099-7.00005-X

39. Pandey A, Nigam P, Soccol CR, Soccol VT, Singh D, Mohan R. Advances in microbial amylases. Biotechnol Appl Biochem. 2000;31 (Pt 2):135-52.

40. Shigechi H, Koh J, FujitaY, Matsumoto T, Bito Y, Ueda M, et al. Direct production of ethanol from raw corn starch via fermentation by use of a novel surface-engineered yeast strain codisplaying glucoamylase and a-amylase. Appl Environ Microbiol. 2004;70(8):5037-40.

https://doi.org/10.1128/AEM.70.8.5037-5040.2004

41. Lee S, Speight JG, Loyalka SK, editors. Handbook of alternative fuel technologies. Boca Raton, FL, USA: CRC Press; 2007. https://doi.org/10.1201/9781420014518

42. Schubert C. Can biofuels finally take center stage? Nat Biotechnol. 2006;24:777-84.

https://doi.org/10.1038/nbt0706-777

43. Tanadul O, VanderGheynst JS, Beckles DM, Powell ALT, Labavitch JM. The impact of elevated $\mathrm{CO} 2$ concentration on the quality of algal starch as a potential biofuel feedstock. Biotechnol Bioeng. 2014;111(7):1323-31.

https://doi.org/10.1002/bit.25203

44. Binod P, Sindhu R, Singhania RR, Vikram S, Devi L, Nagalakshmi $S$, et al. Bioethanol production from rice straw: An overview. Bioresour Technol. 2010;101(13):4767-74. https://doi.org/10.1016/j.biortech.2009.10.079

45. Quintero JA, Rincón LE, Cardona CA. Production of bioethanol from agroindustrial residues as feedstocks. In: Pandey A, Larroche C, Ricke SC, Dussap CG, Gnansounou E, editors. Biofuels - Alternative feedstocks and conversion processes. Oxford, UK: Academic Press; 2011. pp. 251-85. https://doi.org/10.1016/B978-0-12-385099-7.000011-5

46. Dale BE, Kim S. Biomass refining global impact - The biobased economy of the 21st century. In: Kamm B, Gruber PR, Kamm M, editors. Biorefineries - Industrial processes and products (Status quo and future directions). Weinheim, Germany:Wiley-VCH; 2010. pp. 41-66.

https://doi.org/10.1002/9783527619849.ch2

47. Hatti-Kaul R. Biorefineries - A path to sustainability? Crop Sci. 2010;50(Suppl_1):S-152-6. https://doi.org/10.2135/cropsci2009.10.0563

48. Mansfield SD, Mooney C, Saddler JN. Substrate and enzyme characteristics that limit cellulose hydrolysis. Biotechnol Prog. 1999;15(5):804-16.

https://doi.org/10.1021/bp9900864 
49. Kumar R, Wyman CE. Key features of pretreated lignocellulosic biomass solids and their impact on hydrolysis. In:Waldron K, editor. Bioalcohol production - Biochemical conversion of lignocellulosic biomass. Series in Energy: Number 3. Oxford, UK:Woodhead Publishing; 2010. pp. 73-121.

50. Laureano-Perez L, Teymouri F, Alizadeh H, Dale BE. Understanding factors that limit enzymatic hydrolysis of biomass. Appl Biochem Biotechnol. 2005;124(1-3):1081-99. https://doi.org/10.1385/ABAB:124:1-3:1081

51. Mosier N, Wyman C, Dale BD, Elander R, Lee YY, Holtzapple $M$, Ladisch $M$. Features of promising technologies for pretreatment of lignocellulosic biomass. Bioresour Technol. 2005;96(6):673-86. https://doi.org/10.1016/j.biortech.2004.06.025

52. Pan X, Xie D, Gilkes N, Gregg DJ, Saddler JN. Strategies to enhance the enzymatic hydrolysis of pretreated softwood with high residual lignin content. Appl Biochem Biotechnol. 2005;121-24:1069-79.

https://doi.org/10.1385/ABAB:124:1-3:1069

53. Chandra RP, Bura R, Mabee WE, Berlin A, Pan X, Saddler JN. Substrate pretreatment: The key to effective enzymatic hydrolysis of lignocellulosics? In: Olsson L, editor. Biofuels. Advances in biochemical engineering/biotechnology, vol. 108. Berlin, Germany: Springer; 2007. pp. 67-93. https://doi.org/10.1007/10_2007_064

54. Huang HJ, Ramaswamy S, Tschirner UW, Ramarao BV. A review of separation technologies in current and future biorefineries. Sep Purif Technol. 2008;62(1):1-21.

https://doi.org/10.1016/j.seppur.2007.12.011

55. Kucera D, Benesova P, Ladicky P, Pekar M, Sedlacek P, Obruca S. Production of polyhydroxyalkanoates using hydrolyzates of spruce sawdust: Comparison of hydrolyzates detoxification by application of overliming, active carbon, and lignite. Bioengineering. 2017;4(2):53.

https://doi.org/10.3390/bioengineering4020053

56. Taherzadeh MJ, Karimi K. Pretreatment of lignocellulosic wastes to improve ethanol and biogas production: A review. Int J Mol Sci. 2008;9(9):1621-51. https://doi.org/10.3390/ijms9091621

57. Sun Y, Cheng J. Hydrolysis of lignocellulosic materials for ethanol production: A review. Bioresour Technol. 2002;83(1):1-11. https://doi.org/10.1016/S0960-8524(01)00212-7

58. Talebnia F, Karakashev D, Angelidaki I. Production of bioethanol from wheat straw: An overview on pretreatment, hydrolysis and fermentation. Bioresour Technol. 2010;101(13): 4744-53.

https://doi.org/10.1016/j.biortech.2009.11.080

59. Karunanithy C, Muthukumarappan K. Effect of extruder parameters and moisture content of switchgrass, prairie cord grass on sugar recovery from enzymatic hydrolysis. Appl Biochem Biotechnol. 2010;162(6):1785-803.

https://doi.org/10.1007/s12010-010-8959-3
60. Yoo J, Alavi S, Vadlani P, Amanor-Boadu V. Thermo-mechanical extrusion pretreatment for conversion of soybean hulls to fermentable sugars. Bioresour Technol. 2011;102(16): 7583-90.

https://doi.org/10.1016/j.biortech.2011.04.092

61. Kootstra AMJ, Beeftink HH, Scott EL, Sanders JPM. Comparison of dilute mineral and organic acid pretreatment for enzymatic hydrolysis of wheat straw. Biochem Eng J. 2010; 46(2):126-31.

https://doi.org/10.1016/j.bej.2009.04.020

62. Carvalheiro F, Duarte LC, Gírio FM. Hemicellulose biorefineries: A review on biomass pretreatments. J Sci Ind Res (India). 2008;67:849-64.

63. Cheng YS, Zheng Y,Yu CW, DooleyTM, Jenkins BM, VanderGheynst JS. Evaluation of high solids alkaline pretreatment of rice straw. Appl Biochem Biotechnol. 2010;162(6):1768-84. https://doi.org/10.1007/s12010-010-8958-4

64. Kumar P, Barrett DM, Delwiche MJ, Stroeve P. Methods for pretreatment of lignocellulosic biomass for efficient hydrolysis and biofuel production. Ind Eng Chem Res. 2009; 48(8):3713-29.

https://doi.org/10.1021/ie801542g

65. García-Cubero MT, González-Benito G, Indacoechea I, Coca $\mathrm{M}$, Bolado S. Effect of ozonolysis pretreatment on enzymatic digestibility of wheat and rye straw. Bioresour Technol. 2009;100(4):1608-13.

https://doi.org/10.1016/j.biortech.2008.09.012

66. Silverstein RA, Chen Y, Sharma-Shivappa RR, Boyette MD, Osborne J. A comparison of chemical pretreatment methods for improving saccharification of cotton stalks. Bioresour Technol. 2007;98(16):3000-11.

https://doi.org/10.1016/j.biortech.2006.10.022

67. Barros RDROD, Paredes RDS, Endo T, da Silva Bon EP, Lee SH. Association of wet disk milling and ozonolysis as pretreatment for enzymatic saccharification of sugarcane bagasse and straw. Bioresour Technol. 2013;136:288-94.

https://doi.org/0.1016/j.biortech.2013.03.009

68. Olivier-Bourbigou H, Magna L, Morvan D. Ionic liquids and catalysis: Recent progress from knowledge to applications. Appl Catal A. 2010;373(1-2):1-56.

https://doi.org/10.1016/j.apcata.2009.10.008

69. Hayes DJ. An examination of biorefining processes, catalysts and challenges. Catal Today. 2009;145(1-2):138-51. https://doi.org/10.1016/j.cattod.2008.04.017

70. Banerjee C, Mandal S, Ghosh S, Kuchlyan J, Kundu N, Sarkar N. Unique characteristics of ionic liquids comprised of longchain cations and anions: A new physical insight. J Phys Chem B. 2013;117(14):3927-34. https://doi.org/10.1021/jp4015405

71. Zhao H, Baker GA, Cowins JV. Fast enzymatic saccharification of switchgrass after pretreatment with ionic liquids. Biotechnol Prog. 2010;26(1):127-33.

https://doi.org/10.1002/btpr.331 
72. Nguyen TAD, Kim KR, Han SJ, Cho HY, Kim JW, Park SM, et al. Pretreatment of rice straw with ammonia and ionic liquid for lignocellulose conversion to fermentable sugars. Bioresour Technol. 2010;101(19):7432-8.

https://doi.org/10.1016/j.biortech.2010.04.053

73. da Costa Lopes AM, João KG, Rubik DF, Bogel-Łukasik E, Duarte LC, Andreaus J, Bogel-Kukasik R. Pre-treatment of lignocellulosic biomass using ionic liquids: Wheat straw fractionation. Bioresour Technol. 2013;142:198-208. https://doi.org/10.1016/j.biortech.2013.05.032

74. Park N, Kim HY, Koo BW, Yeo H, Choi IG. Organosolv pretreatment with various catalysts for enhancing enzymatic hydrolysis of pitch pine (Pinus rigida). Bioresour Technol. 2010;101(18):7046-53.

https://doi.org/10.1016/j.biortech2010.04.020

75. Mesa L, González E, Cara C, González M, Castro E, Mussatto SI. The effect of organosolv pretreatment variables on enzymatic hydrolysis of sugarcane bagasse. Chem Eng J. 2011; 168(3):1157-62.

https://doi.org/10.1016/j.cej.2011.02.003

76. Sun F, Chen H. Organosolv pretreatment by crude glycerol from oleochemicals industry for enzymatic hydrolysis of wheat straw. Bioresour Technol. 2008;99(13):5474-9.

https://doi.org/10.1016/j.biortech.2007.11.001

77. Öhgren K, Vehmaanperä J, Siika-Aho M, Galbe M, Viikari L, Zacchi G. High temperature enzymatic prehydrolysis prior to simultaneous saccharification and fermentation of steam pretreated corn stover for ethanol production. Enzyme Microb Technol. 2007;40(4):607-13.

https://doi.org/10.1016/j.enzmictec.2006.05.014

78. Amores I, Ballesteros I, Manzanares P, Sáez F, Michelena G, Ballesteros M. Ethanol production from sugarcane bagasse pretreated by steam explosion. Electron J Energ Environ. 2013;1(1):25-36.

https://doi.org/10.7770/ejee-V1N1-art519

79. Lau MJ, Lau MW, Gunawan C, Dale BE. Ammonia fiber expansion (AFEX) pretreatment, enzymatic hydrolysis, and fermentation on empty palm fruit bunch fiber (EPFBF) for cellulosic ethanol production. Appl Biochem Biotechnol. 2010;162(7):1847-57.

https://doi.org/10.1007/s12010-010-8962-8

80. Gao M, Xu F, Li S, Ji X, Chen S, Zhang D. Effect of SC-CO pretreatment in increasing rice straw biomass conversion. Biosyst Eng. 2010;106(4):470-5. https://doi.org/10.1016/j.biosystemseng.2010.05.011

81. Benazzi T, Calgaroto S, Astolfi V, Rosa CD, Oliveira JV, Mazutti MA. Pretreatment of sugarcane bagasse using supercritical carbon dioxide combined with ultrasound to improve the enzymatic hydrolysis. Enzyme Microb Technol. 2013;52(45):247-50.

https://doi.org/10.1016/j.enzmictec.2013.02.001

82. Wang GS, Pan XJ, Zhu JY, Gleisner R, Rockwood D. Sulfite pretreatment to overcome recalcitrance of lignocellulose
(SPORL) for robust enzymatic saccharification of hardwoods. Biotechnol Prog. 2009;25(4):1086-93.

https://doi.org/10.1002/btpr.206

83. Zhu JY, Pan XJ, Wang GS, Gleisner R. Sulfite pretreatment (SPORL) for robust enzymatic saccharification of spruce and red pine. Bioresour Technol. 2009;100(8):2411-8.

https://doi.org/10.1016/j.biortech.2008.10.057

84. Zhu JY, Zhu W, OBryan P, Dien BS, Tian S, Gleisner R, Pan XJ. Ethanol production from SPORL-pretreated lodgepole pine: Preliminary evaluation of mass balance and process energy efficiency. Appl Microbiol Biotechnol. 2010;86(5):1355-65. https://doi.org/10.1007/s00253-009-2408-7

85. Zhu W, Zhu JY, Gleisner R, Pan XJ. On energy consumption for size-reduction and yields from subsequent enzymatic saccharification of pretreated lodgepole pine. Bioresour Technol. 2010:101(8):2782-92.

https://doi.org/10.1016/j.biortech.2009.10.076

86. Zhu JY, Pan XJ. Woody biomass pretreatment for cellulosic ethanol production: Technology and energy consumption evaluation. Bioresour Technol. 2010;101(13):4992-5002.

https://doi.org/10.1016/j.biortech.2009.11.007

87. Sarkar N, Ghosh SK, Bannerjee S, Aikat K. Bioethanol production from agricultural wastes: An overview. Renew Energy. 2012;37(1):19-27. https://doi.org/10.1016/j.renene.2011.06.045

88. Su MY, Tzeng WS, Shyu YT. An analysis of feasibility of bioethanol production from Taiwan sorghum liquor waste. Bioresour Technol. 2010;101(17):6669-75. https://doi.org/10.1016/j.biortech.2010.03.105

89. Bussemaker MJ, Zhang D. Effect of ultrasound on lignocellulosic biomass as a pretreatment for biorefinery and biofuel applications. Ind Eng Chem Res. 2013;52(10):3563-80. https://doi.org/10.1021/ie3022785

90. Sánchez C. Lignocellulosic residues: Biodegradation and bioconversion by fungi. Biotechnol Adv. 2009;27(2):185-94. https://doi.org/10.1016/j.biotechadv.2008.11.001

91. Wan C, Li Y. Effectiveness of microbial pretreatment by Ceriporiopsis subvermispora on different biomass feedstocks. Bioresour Technol. 2011;102(16):7507-12. https://doi.org/10.1016/j.biortech.2011.05.026

92. Prasad S, Singh A, Joshi HC. Ethanol as an alternative fuel from agricultural, industrial and urban residues. Resour Conserv Recycl. 2007;50(1):1-39. https://doi.org/10.1016/j.resconrec.2006.05.007

93. Rabinovich ML, Melnik MS, Bolobova AV. Microbial cellulases (review). Appl Biochem Microbiol. 2002;38(4):305-22. https://doi.org/10.1023/A:1016264219885

94. Galbe M, Zacchi G. A review of the production of ethanol from softwood. Appl Microbiol Biotechnol. 2002;59(6): 618-28. https://doi.org/10.1007/s00253-002-1058-9 
95. Mussatto SI, Teixeira JA. Lignocellulose as raw material in fermentation processes. In: Méndes-Vilas A, editor. Current research, technology and education topics in applied microbiology and microbial biotechnology, vol. 2. Badajoz, Spain: Formatex Research Center; 2010. pp. 897-907.

96. Ivančić Šantek M, Miškulin E, Beluhan S, Šantek B. New trends in the ethanol production as a biofuel. Kem Ind. 2016;65 (1-2):25-38.

https://doi.org/10.15255/KUl.2014.032

97. Sánchez ÓJ, Cardona CA. Trends in biotechnological production of fuel ethanol from different feedstocks. Bioresour Technol. 2008;99(13):5270-95.

https://doi.org/10.1016/j.biortech.2007.11.013

98. Narendranath NV, Thomas KC, Ingledew WM. Urea hydrogen peroxide reduces the numbers of lactobacilli, nourishes yeast, and leaves no residues in the ethanol fermentation. Appl Environ Microbiol. 2000;66(10):4187-92. https://doi.org/10.1128/AEM.66.10.4187-4192.2000

99. Bai FW, Anderson WA, Moo-Young M. Ethanol fermentation technologies from sugar and starch feedstocks. Biotechnol Adv. 2008;26(1):89-105.

https://doi.org/10.1016/j.biotechadv.2007.09.002

100. Bai FW, Chen LJ, Anderson WA, Moo-Young M. Parameter oscillations in very high gravity medium continuous ethanol fermentation and their attenuation on multistage packed column bioreactor system, Biotechnol Bioeng. 2004;88(5):558-66.

https://doi.org/10.1002/bit.20221

101. Bothast RJ, Schlicher MA. Biotechnological processes for conversion of corn into ethanol. Appl Microbiol Biotechnol. 2005;67(1):19-25.

https://doi.org/10.1007/s00253-004-1819-8

102. Kelsall DR, Lyons TP. Grain dry milling and cooking procedures: Extracting sugars in preparation for fermentation. In: Jacques KA, Lyons TP, Kelsall DR, editors. The alcohol textbook. Nottingham, UK: Nottingham University Press; 2003. pp. 9-22.

103. Cardona CA, Sánchez ÓJ. Fuel ethanol production: Process design trends and integration opportunities. Bioresour Technol. 2007;98(12):2415-57.

https://doi.org/10.1016/j.biortech.2007.01.002

104. Bhatia L, Johri S, Ahmad R. An economic and ecological perspective of ethanol production from renewable agro waste: A review. AMB Express. 2012;2:65. https://doi.org/10.1186/2191-0855-2-65

105. Kang Q, Appels L, Tan T, Dewil R. Bioethanol from lignocellulosic biomass: Current findings determine research priorities. Sci World J. 2014;2014:Article ID 298153.

https://doi.org/10.1155/2014/298153

106. Gupta A, Verma JP. Sustainable bio-ethanol production from agro-residues: A review. Renew Sust Energ Rev. 2015; 41:550-67.

https://doi.org/10.1016/j.rser.2014.08.032
107. Haq F, Ali H, Shuaib M, Badshah M, Hassan SW, Munis MFH, Chaudhary HJ. Recent progress in bioethanol production from lignocellulosic materials: A review. Int J Green Energy. 2016;13(14):1413-41.

https://doi.org/10.1080/15435075.2015.1088855

108. Chu BC, Lee H. Genetic improvement of Saccharomyces cerevisiae for xylose fermentation. Biotechnol Adv. 2007; 25(5):425-41. https://doi.org/10.1016/j.biotechadv.2007.04.001

109. Quintero JA, Cardona CA. Process simulation of fuel ethanol production from lignocellulosics using aspen plus. Ind Eng Chem Res. 2011;50(10):6205-12. https://doi.org/10.1021/ie101767x

110. Claassen PAM, van Lier JB, Lopez Contreras A, van Niel EWJ, Sijtsma L, Stams AJM, et al. Utilisation of biomass for the supply of energy carriers. Appl Microbiol Biotechnol. 1999;52(6):741-55. https://doi.org/10.1007/s002530051586

111. Jeffries TW, Shi NQ. Genetic engineering for improved $x y$ lose fermentation by yeasts. In: Tsao GT, Brainard AP, Bungay HR, Cao NJ, Cen P, Chen Z, et al., editors. Recent progress in bioconversion of lignocellulosics. Advances in biochemical engineering/biotechnology, vol. 65. Berlin, Germany: Springer; 1995. pp. 117-61.

112. Baeyens J, Kang Q, Appels L, Dewil R, LvY, Tan T. Challenges and opportunities in improving the production of bio-ethanol. Prog Energy Combust Sci. 2015;47:60-88.

https://doi.org/10.1016/j.pecs.2014.10.003

113. Conway T. The Entner-Doudoroff pathway: History, physiology and molecular biology. FEMS Microbiol Rev. 1992; 9(1):1-27.

https://doi.org/10.1016/0378-1097(92)90334-K

114. Okamoto T, Taguchi H, Nakamura K, Ikenaga H, Kuraishi H, Yamasato K. Zymobacter palmae gen. nov., sp. nov., a new ethanol-fermenting peritrichous bacterium isolated from palm sap. Arch Microbiol. 1993;160(5):333-7.

https://doi.org/10.1007/BF00252218

115. Panagiotou G, Villas-Bôas SG, Christakopoulos P, Nielsen J, Olsson L. Intracellular metabolite profiling of Fusarium oxysporum converting glucose to ethanol. J Biotechnol. 2005; 115(4):425-34. https://doi.org/10.1016/j.jbiotec.2004.09.011

116. Philippidis GP, Smith TK. Limiting factors in the simultaneous saccharification and fermentation process for conversion of cellulosic biomass to fuel ethanol. Appl Biochem Biotechnol. 1995;51(1):117-24. https://doi.org/10.1007/BF02933416

117. Brethauer S, Wyman CE. Review: Continuous hydrolysis and fermentation for cellulosic ethanol production. Bioresour Technol. 2010;101(13):4862-74. https://doi.org/10.1016/j.biortech.2009.11.009

118. Ballesteros I, Ballesteros M, Cabañas A, Carrasco J, Martín C, Negro MJ, et al. Selection of thermotolerant yeasts 
for simultaneous saccharification and fermentation (SSF) of cellulose to ethanol. Appl Biochem Biotechnol. 1991;28/29: 307-15.

https://doi.org/10.1007/BF02922610

119. Yadav KS, Naseeruddin S, Prashanthi GS, Sateesh L, Rao LV. Bioethanol fermentation of concentrated rice straw hydrolysate using co-culture of Saccharomyces cerevisiae and Pichia stipitis. Bioresour Technol. 2011;102(11):6473-8. https://doi.org/10.1016/j.biortech.2011.03.019

120. Sornvoraweat B, Kongkiattikajorn J. Separated hydrolysis and fermentation of water hyacinth leaves for ethanol production. Khon Kaen University Res J. 2010;15(9):794-802.

121. Olsson L, Hahn-Hägerdal B. Fermentation of lignocellulosic hydrolysates for ethanol production. Enzyme Microb Technol. 1996;18(5):312-31.

https://doi.org/10.1016/0141-0229(95)00157-3

122. Chandrakant $P$, Bisaria VS. Simultaneous bioconversion of cellulose and hemicellulose to ethanol. Crit Rev Biotechnol. 1998;18(4):295-331.

https://doi.org/10.1080/0738-859891224185

123. Lynd LR, van Zyl WH, McBride JE, Laser M. Consolidated bioprocessing of cellulosic biomass: An update. Curr Opin Biotechnol. 2005;16(5):577-83.

https://doi.org/10.1016/j.copbio.2005.08.009

124. Sakamoto T, Hasunuma T, Hori Y, Yamada R, Kondo A. Direct ethanol production from hemicellulosic materials of rice straw by use of an engineered yeast strain codisplaying three types of hemicellulolytic enzymes on the surface of xylose-utilizing Saccharomyces cerevisiae cells. J Biotechol. 2012;158(4):203-10.

https://doi.org/10.1016/j.jbiotec.2011.06.025

125. Ishola MM, Jahandideh A, Haidarian B, Brandberg T, Taherzadeh MJ. Simultaneous saccharification, filtration and fermentation (SSFF): A novel method for bioethanol production from lignocellulosic biomass. Bioresour Technol. 2013; 133:68-73.

https://doi.org/10.1016/j.biortech.2013.01.130

126. Ishola MM, Brandberg T, Taherzadeh MJ. Simultaneous glucose and xylose utilization for improved ethanol production from lignocellulosic biomass through SSFF with encapsulated yeast. Biomass Bioenergy. 2015;77:192-9. https://doi.org/10.1016/j.biombioe.2015.03.021

127. Ferreira V, de Oliveira Faber M, da Silva Mesquita S, Pereira Jr N. Simultaneous saccharification and fermentation process of different cellulosic substrates using a recombinant Saccharomyces cerevisiae harbouring the $\beta$-glucosidase gene. Electron J Biotech. 2010;13(2).

https://doi.org/10.2225/vol13-issue2-fulltext-1

128. Wirawan F, Cheng CL, Kao WC, Lee DJ, Chang JS. Cellulosic ethanol production performance with SSF and SHF processes using immobilized Zymomonas mobilis. Appl Energy. 2012;100:19-26.

https://doi.org/10.1016/j.apenergy.2012.04.032
129. Yáñez-S M, Rojas J, Castro J, Ragauskas A, Baeza J, Freer J. Fuel ethanol production from Eucalyptus globulus wood by autocatalized organosolv pretreatment ethanol-water and SSF. J Chem Technol Biotechnol. 2013;88(1):39-48. https://doi.org/10.1002/jctb.3895

130. Suriyachai N, Weerasaia K, Laosiripojana N, Champreda V, Unrean P. Optimized simultaneous saccharification and co-fermentation of rice straw for ethanol production by Saccharomyces cerevisiae and Scheffersomyces stipitis co-culture using design of experiments. Bioresour Technol. 2013;142:171-8.

https://doi.org/10.1016/j.biortech.2013.05.003

131. Jin M, Sarks C, Gunawan C, Bice BD, Simonett SP, Narasimhan RA, et al. Phenotypic selection of a wild Saccharomyces cerevisiae strain for simultaneous saccharification and co-fermentation of AFEX ${ }^{\mathrm{TM}}$ pretreated corn stover. Biotechnol Biofuels. 2013;6:108.

https://doi.org/10.1186/1754-6834-6-108

132. Yanase S, Hasunuma T, Yamada R, Tanaka T, Ogino C, Fukuda $\mathrm{H}$, Kondo A. Direct ethanol production from cellulosic materials at high temperature using the thermotolerant yeast Kluyveromyces marxianus displaying cellulolytic enzymes. Appl Microbiol Biotechnol. 2010;88(1):381-8. https://doi.org/10.1007/s00253-010-2784-z

133. Jin M, Gunawan C, Balan V, Dale, BE. Consolidated bioprocessing (CBP) of AFEX ${ }^{\mathrm{TM}}$-pretreated corn stover for ethanol production using Clostridium phytofermentans at a high solids loading. Biotechnol Bioeng. 2012;109(8):1929-36. https://doi.org/10.1002/bit.24458

134. Huang K, Zhan D, Nakaiwa M, Nakane T, Takamatsu T. Modeling and analysis of internally heat integrated distillation column. Chin J Chem Eng. 1999;7:67-76.

135. Mulia-Soto JF, Flores-Tlacuahuac A. Modeling, simulation and control of an internally heat integrated pressure-swing distillation process for bioethanol separation. Comput Chem Eng. 2011;35(8):1532-46.

https://doi.org/10.1016/j.compchemeng.2011.03.011

136. Ligero EL, Ravagnani TMK. Dehydration of ethanol with salt extractive distillation - A comparative analysis between processes with salt recovery. Chem Eng Process. 2003;42(7):543-52.

https://doi.org/10.1016/S0255-2701(02)00075-2

137. Lei Z, Li C, Chen B. Extractive distillation: A review. Sep Purif Rev. 2003;32(2):121-213.

https://doi.org/10.1081/SPM-120026627

138. Hua C, Li X, Xu S, Bai P. Design and operation of batch extractive distillation with two reboilers. Chin J Chem Eng. 2007;15(2):286-90. https://doi.org/10.1016/S1004-9541(07)60072-X

139. Kotai B, Lang P, Modla G. Batch extractive distillation as hybrid process: Separation of minimum boiling azeotropes. Chem Eng Sci. 2007;62(23):6816-26. https://doi.org/10.1016/j.ces.2006.10.002 
140. Vasconcelos CJG, Wolf-Maciel MR. Dynamic and control of high purity heterogeneous azeotropic distillation process. Comput Aided Chem Eng. 2000;8:217-22. https://doi.org/10.1016/S1570-7946(00)80038-3

141. Gomis V, Pedraza R, Francés O, Font A, Asensi JC. Dehydration of ethanol using azeotropic distillation with isooctane. Ind Eng Chem Res. 2007;46(13):4572-6.

https://doi.org/10.1021/ie0616343

142. Shukla R, Cheryan M. Performance of ultrafiltration membranes in ethanol-water solutions: Effect of membrane conditioning. J Membr Sci. 2002;198(1):75-85. https://doi.org/10.1016/S0376-7388(01)00638-X

143. Lee EKL, BabcockWC, Bresnahan PA. Ethanol-water separation by countercurrent reverse osmosis. ACS Symposium Series, vol. 269. Washington, DC, USA: American Chemical Society; 1985 . pp. 409-28.

https://doi.org/10.1021/bk-1985-0269.ch019

144. Radočaj O, Diosady LL. Continuous ethanol fermentation in immersed, cross-flow microfiltration membrane bioreactor with cell retention. J Basic Appl Sci. 2014;10:543-53. https://doi.org/10.6000/1927-5129.2014.10.73

145. Hwang KJ, Ku CY. Model development for estimating microfiltration performance of bio-ethanol fermentation broth. J Taiwan Inst Chem Eng. 2014;45(4):1233-40.

https://doi.org/10.1016/j.jtice.2014.01.001

146. Wu Y, Huang W, Xiao Z, Zhong Y. Ethanol recovery from fermentation broth by pervaporation using a composite polydimethylsiloxane membrane. Chin J Chem Eng. 2004; 12(4):586-9.

147. Xiangli F, Wei W, Chen Y, Jin W, Xu N. Optimization of preparation conditions for polydimethylsiloxane (PDMS)/ceramic composite pervaporation membranes using response surface methodology. J Membr Sci. 2008;311(1-2):23-33. https://doi.org/10.1016/j.memsci.2007.11.054

148. Chovau S, Gaykawad S, Straathof AJJ, Van der Bruggen B. Influence of fermentation by-products on the purification of ethanol from water using pervaporation. Bioresour Technol. 2011;102(2):1669-74.

https://doi.org/10.1016/j.biortech.2010.09.092

149. Peng P, Shi B, Lan Y. A review of membrane materials for ethanol recovery by pervaporation. Sep Sci Technol. 2011; 46(2):234-46.

https://doi.org/10.1080/01496395.2010.504681

150. Nomura M, Bin T, Nakao S. Selective ethanol extraction from fermentation broth using a silicalite membrane. Sep Purif Technol. 2002;27(1):59-66. https://doi.org/10.1016/S1383-5866(01)00195-2

151. Ma Y, Li X, Jia P, Ma Y, Liu N, Zhang H. Preparation of zein-based membranes and their pervaporation for ethanol aqueous solution. Desalination. 2012;299:70-8.

https://doi.org/10.1016/j.desal.2012.05.024
152. Kaewkannetra P, Chutinate N, Moonamart S, Kamsan T, Chiu TY. Separation of ethanol from ethanol-water mixture and fermented sweet sorghum juice using pervaporation membrane reactor. Desalination. 2011;271(1-3):88-91. https://doi.org/10.1016/j.desal.2010.12.012

153. Cai D, Hu S, Chen C, Wang Y, Zhang C, Miao Q, et al. Immobilized ethanol fermentation coupled to pervaporation with silicalite-1/polydimethylsiloxane/polyvinylidene fluoride composite membrane. BioresourTechnol. 2016;220:124-31. https://doi.org/10.1016/j.biortech.2016.08.036

154. Marjani A, Mohammadi M, Pelalak R, Moradi S. Ethanol purification using polyamide-carbon nanotube composite membranes. Polym Eng Sci. 2014;54(4):961-8.

https://doi.org/10.1002/pen.23635

155. Weilnhammer C, Blass E. Continuous fermentation with product recovery by in-situ extraction. Chem Eng Technol. 1994;17(6):365-73.

https://doi.org/10.1002/ceat.270170602

156. Boudreau TM, Hill GA. Improved ethanol-water separation using fatty acids. Process Biochem. 2006;41(4):980-3. https://doi.org/10.1016/j.procbio.2005.11.006

157. Offeman RD, Stephenson SK, Robertson GH, Orts WJ. Solvent extraction of ethanol from aqueous solutions using biobased oils, alcohols, and esters. J Am Oil Chem Soc. 2006;83(2):153-7. https://doi.org/10.1007/s11746-006-1188-9

158. Offeman RD, Stephenson SK, Franqui D, Cline JL, Robertson GH, Orts WJ. Extraction of ethanol with higher alcohol solvents and their toxicity to yeast. Sep Purif Technol. 2008; 63(2):444-51. https://doi.org/10.1016/j.seppur.2008.06.005

159. Offeman RD, Stephenson SK, Franqui-Espiet D, Cline JL, Robertson GH, Orts WJ. Extraction of ethanol with higher carboxylic acid solvents and their toxicity to yeast. Sep Purif Technol. 2010;72(2):180-5.

https://doi.org/10.1016/j.seppur.2010.02.004

160. Ezeji TC, Qureshi N, Blaschek HP. Production of acetone, butanol and ethanol by Clostridium beijerinckii BA101 and in situ recovery by gas stripping. World J Microbiol Biotechnol. 2003;19(6):595-603. https://doi.org/10.1023/A:1025103011923

161. Ezeji TC, Qureshi N, Blaschek HP. Acetone butanol ethanol $(\mathrm{ABE})$ production from concentrated substrate: Reduction in substrate inhibition by fed-batch technique and product inhibition by gas stripping. Appl Microbiol Biotechnol. 2004;63(6):653-8. https://doi.org/10.1007/s00253-003-1400-x

162. de Vrije $T$, Budde $M$, van der Wal H, Claassen PAM, López-Contreras AM. 'In situ' removal of isopropanol, butanol and ethanol from fermentation broth by gas stripping Bioresour Technol. 2013;137:153-9.

https://doi.org/10.1016/j.biortech.2013.03.098 
163. Zhang J, Liu HJ, Liu DH. Effect of different types of gas in gas stripping ethanol fermentation (GSEF). Chin J Process Eng. 2005;5(3):349-52.

164. Ezeji TC, Karcher PM, Qureshi N, Blaschek HP. Improving performance of a gas stripping-based recovery system to remove butanol from Clostridium beijerinckii fermentation. Bioprocess Biosyst Eng. 2005;27(3):207-14. https://doi.org/10.1007/s00449-005-0403-7

165. Xue C, Zhao J, Lu C, Yang ST, Bai F, Tang IC. High-titer n-butanol production by Clostridium acetobutylicum JB200 in fed-batch fermentation with intermittent gas stripping. Biotechnol Bioeng. 2012;109(11):2746-56.

https://doi.org/10.1002/bit.24563

166. Lu C, Zhao J, Yang ST, Wei D. Fed-batch fermentation for butanol production from cassava bagasse hydrolysate in a fibrous bed bioreactor with continuous gas stripping. Bioresour Technol. 2012;104:380-7.

https://doi.org/10.1016/j.biortech.2011.10.089

167. Taylor F, Kurantz MJ, Goldberg N, Craig Jr. JC. Effects of ethanol concentration and stripping temperature on continuous fermentation rate. Appl Microbiol Biotechnol. 1997;48(3):311-6.

https://doi.org/10.1007/s002530051055

168. Taylor F, Kurantz MJ, Goldberg N, Craig Jr. JC. Kinetics of continuous fermentation and stripping of ethanol. Biotechnol Lett. 1998;20(1):67-72.

https://doi.org/10.1023/A:1005339415979

169. Taylor F, Kurantz MJ, Goldberg N, McAloon AJ, Craig Jr. JC. Dry-grind process for fuel ethanol by continuous fermentation and stripping. Biotechnol Prog. 2000;16(4):541-7. https://doi.org/10.1021/bp0000297

170. Chen HZ, Liu ZH, Da SH. A novel solid state fermentation coupled with gas stripping enhancing the sweet sorghum stalk conversion performance for bioethanol. Biotechnol Biofuels. 2014;7:53.

https://doi.org/10.1186/1754-6834-7-53

171. Ponce GHSF, Miranda JCC, Alves M, Wolf MRM, Filho RM, de Andrade RR, de Conto LC. Simulation, analysis and optimization of an in situ gas stripping fermentation process in a laboratory scale for bioethanol production. Chem Eng Trans. 2014;37:295-300. https://doi.org/10.3303/CET1543054

172. Oumi Y, Miyajima A, Miyamoto J, Sano T. Binary mixture adsorption of water and ethanol on silicalite. Stud Surf Sci Catal. 2002;142:1595-602. https://doi.org/10.1016/S0167-2991(02)80329-9

173. Qureshi N, Hughes S, Maddox IS, Cotta MA. Energy-efficient recovery of butanol from model solutions and fermentation broth by adsorption. Bioprocess Biosyst Eng. 2005;27(4):215-22.

https://doi.org/10.1007/s00449-005-0402-8

174. Bowen TC, Vane LM. Ethanol, acetic acid, and water adsorption from binary and ternary liquid mixtures on high-silica zeolites. Langmuir. 2006;22(8):3721-7.

https://doi.org/10.1021/la052538u

175. Fujita H, Qian Q, Fujii T, Mochizuki K, Sakoda A. Isolation of ethanol from its aqueous solution by liquid phase adsorption and gas phase desorption using molecular sieving carbon. Adsorption 2011;17(5):869-79.

https://doi.org/10.1007/s10450-011-9354-2

176. Cartón A, González Benito G, Rey JA, de la Fuente M. Selection of adsorbents to be used in an ethanol fermentation process. Adsorption isotherms and kinetics. Bioresour Technol. 1998;66(1):75-8.

https://doi.org/10.1016/S0960-8524(98)00048-0

177. Jones RA, Gandier JA, Thibault J, Tezel FH. Enhanced ethanol production through selective adsorption in bacterial fermentation. Biotechnol Bioprocess Eng. 2011;16(3):531-41. https://doi.org/10.1007/s12257-010-0299-1

178. Onuki S, Koziel JA, van Leeuwen J, Jenks WS, Grewell DA, Cai L. Purification and quality enhancement of fuel ethanol to produce industrial alcohols with ozonation and activated carbon: Method developments for quantification of impurities and their removal mechanisms. Agricultural and Biosystems Engineering Conference Proceedings and Presentations. 2008 ASABE Annual International Meeting. Providence, RI, USA: American Society of Agricultural and Biological Engineers; 2008. Available from: https://lib.dr.iastate.edu/abe_eng_conf/92.

179. Onuki S, Koziel JA, Jenks WS, Cai L, Rice S, van Leeuwen J. Ethanol purification with ozonation, activated carbon adsorption, and gas stripping. Sep Purif Technol. 2015;151: 165-71.

https://doi.org/10.1016/j.seppur.2015.07.026

180. Hashi M, Tezel FH, Thibault J. Ethanol recovery from fermentation broth via carbon dioxide stripping and adsorption. Energy Fuels. 2010;24(9):4628-37.

https://doi.org/10.1021/ef901130q

181. Pyrgakis KA, de VrijeT, Budde MAW, Kyriakou K, López-Contreras AM, Kokossis AC. A process integration approach for the production of biological iso-propanol, butanol and ethanol using gas stripping and adsorption as recovery methods. Biochem Eng J. 2016;116(5):176-94.

https://doi.org/10.1016/j.bej.2016.07.014 